NBER WORKING PAPER SERIES

\title{
LAND AND POWER: THEORY AND EVIDENCE FROM CHILE
}

\author{
Jean-Marie Baland \\ James A. Robinson \\ Working Paper 12517 \\ http://www.nber.org/papers/w12517
}

\author{
NATIONAL BUREAU OF ECONOMIC RESEARCH \\ 1050 Massachusetts Avenue \\ Cambridge, MA 02138 \\ September 2006
}

We are grateful to Mauricio Benitez-Iturbe and Sebastian Mazzuca for their outstanding research assistance. Our greatest debt is to Jonathan Conning who persevered through at least three previous versions. We have also benefitted from the suggestions and advice of Daron Acemoglu, Siwan Anderson, Arnold Bauer, Samuel Bowles, Michael Carter, Eduardo Fajnzylberg, Jeffry Frieden, Tu Jarvis, Sebastian Laurent, Francois Maniquet, Dina Mesbah, Sripad Motiram, Andrew Newman, Thomas Piketty, Timothy Scully, William Summerhill, Werner Troesken, and numerous seminar participants, particularly Timothy Besley, Alberto Diaz-Cayeros, Esther Duflo, Jim Fearon, Dilip Mookherjee, Jeffrey Nugent, T.N. Srinivasan and Barry Weingast. Jean-Marie Baland would like to thank the MacArthur network on Inequality and Economic Performance, the CRED for financial support and the Belgian Program on Inter-University Poles of Attraction initiated by the Belgian State, Prime Minister's office, Science Policy Programming. The views expressed herein are those of the author(s) and do not necessarily reflect the views of the National Bureau of Economic Research.

(C)2006 by Jean-Marie Baland and James A. Robinson. All rights reserved. Short sections of text, not to exceed two paragraphs, may be quoted without explicit permission provided that full credit, including () notice, is given to the source. 
Land and Power: Theory and Evidence from Chile

Jean-Marie Baland and James A. Robinson

NBER Working Paper No. 12517

September 2006

JEL No. D72, O54, Q15

\begin{abstract}
$\underline{\text { ABSTRACT }}$
We study the connection between employment and political control. Many employment relationships concede rents to workers. For example, when worker effort is crucial for production, but only imperfectly observed. We show that, depending on the political institutions, the presence of such rents allows employers to use the threat of withdrawing them to control their workers' political behavior. We thus demonstrate that employment does not simply generate income, it also gives power to control the behavior of others. The analysis focuses on the salient example of political control, where landlords coerce the votes of their workers in the absence of a secret ballot. The model we develop generates predictions about electoral outcomes which can be tested by investigating the impact of the introduction of an effective secret ballot. Such an institutional reform reduces landlords' control, and in consequence, we should observe changes in voting behavior, since workers whose votes were previously controlled and sold can now vote freely. We test the predictions of the model by examining in detail the effects of the introduction of the secret ballot in Chile in 1958. We show that, consistent with our theory, the political reforms led to large changes in voting behavior. Before the reforms, localities with more pervasive patron-client relationships tend to exhibit a much stronger support for the right-wing parties, traditionally associated with the landed oligarchy. After the reform however, this difference across localities completely disappeared.
\end{abstract}

Jean-Marie Baland

Cred, Department of Economics

FUNDP

8, rempart de la vierge

B5000 Namur

BELGIUM

jean-marie.baland@fundp.ac.be

James A. Robinson

Harvard University

Department of Government

N309, 1737 Cambridge Street

Cambridge, MA 02138

and NBER

jrobinson@gov.harvard.edu 
"It is the most cruel mockery to tell a man he may vote for A or B, when you know that he is so much under the influence of $\mathrm{A}$, or the friends of $\mathrm{A}$, that his voting for $\mathrm{B}$ would be attended with the destruction of him. It is not he who has the vote, really and substantially, but his landlord, for it is for his benefit and interest that it is exercised in the present system." David Ricardo ([1824], 1951-1973, p. 506)

\section{Introduction}

In this paper we study the connection between employment and political control. Many employment relationships concede rents to workers. For example, when worker effort is crucial for production, but only imperfectly observed. We show that the fact that employers already concede rents to workers may allow them, depending on the political institutions, to use the threat of withdrawing these rents to control their political behavior. We thus demonstrate that employment does not simply generate income, it also gives power to control the behavior of others.

The most salient example of such a connection arises in the absence of a secret ballot. When voting is not secret, it becomes feasible to buy, sell and coerce votes. While there are recorded instances of an individualized market for votes, the main stylized fact which emerges from the case study literature is that rather than individuals freely selling their votes to politicians, employers usually control and supply the votes of their employees in exchange for money, favors or policies. More specifically, as discussed by Ricardo (1824), employers are usually landlords.

That landlords control the political activities of their workers has historically been a pervasive characteristic of agrarian economies. ${ }^{1}$ In Britain, before the introduction of the secret ballot in 1872, this factor was critical in determining the outcome of rural elections. As observed by Lord Stanley in 1841,

"when any man attempted to estimate the probable result of a county election in England, it was ascertained by calculating the number of

\footnotetext{
${ }^{1}$ As Malefakis (1970, p. 98) summarized the situation in nineteenth century rural Andalucía, "a man's job depended on his vote."
} 
the great landed proprietors in the county and weighing the number of occupiers under them." 2

Throughout the nineteenth century radicals and reformers complained about the lack of a secret ballot in Britain (see Kinzer, 1982, Cox, 1987 and Gash, 1977). In Germany, despite the fact that a democratic parliament was introduced in 1848 there is a mass of evidence that rural voters were controlled by landed interests. Bismarck even supported an extension of voting rights in 1871 because he thought that the control exercised by landlords over rural voters would offset the rising influence of urban workers (Bendix's, 1964, p. 97, Hamerow 1974, pp. 299-300).

Landlords control over rural elections was greatly facilitated where balloting was open (see Goldstein, 1983, p. 15). However, even when there was a supposedly secret ballot (and not open voting), strategies were found to keep voting under control. Thus, in the German case, political parties often printed their own ballots: "given that ballots had to be obtained from the candidates themselves or from their agents, it was often physically impossible for a poor man to vote for anyone but the squire's choice." (Anderson, 1993, p. 1467) ${ }^{3}$ Even countries, such as France which moved early to universal male suffrage (after 1848) and free elections (after 1871) only introduced an effective (though non-Australian) ${ }^{4}$ secret ballot in 1913. Before this "the ballots frequently had subtle but distinct marks, such as paper thickness, colour and size, from which the election officials could deduce a voter's decision. This information was then passed on to notables who could easily punish such wayward voters since they frequently were his tenants or employees," (Kreuzer 1996, p. 108).

Similar tactics were used and remain up to the present day in democratic third

\footnotetext{
${ }^{2}$ Quoted in Kitson-Clark (1951, p. 112). O'Gorman (1989, p.20) estimates that by 1807 this resulted in the outcomes of 300 parliamentary seats being a foregone conclusion. He describes in detail the system of patronage linking high politicians such as Walpole with members of parliament, typically Whig 'oligarchs,' who controlled the local electorate.

${ }^{3}$ For further evidence on the German case see Blackbourn (1988) and the section on Germany in Gibson and Blinkhorn (1991).

${ }^{4}$ The 'Australian ballot' has become synonymous with perfectly secret voting and refers to a situation where all political alternatives are on a single government produced ballot paper. It derives its name from the fact that the first use of such a ballot was in Australia in 1856 .
} 
world countries. ${ }^{5}$ Nowhere is the evidence about landlord control of elections so conclusive as in Latin America. Following independence most Latin American countries adopted liberal constitutions committing themselves to regular elections, yet, with few exceptions Latin American societies did not become consolidated democracies with free regular elections contested by all adults until the 1980's. ${ }^{6}$ In Colombia, the country which has the longest experience of formal democracy in Latin America and where the military has played the most marginal of political roles, the equivalent of the Australian ballot was legislated only in 1988 and introduced first in 1990. In Chile the control of voting by landowners was very frankly discussed in the debate leading up to the introduction of the secret ballot in 1958 in language strikingly similar to that used by Lord Stanley quoted above. For example, Socialist senator Martones argued in favor of introducing the secret ballot because,

"if that law [the old electoral law without a secret ballot] did not exist, instead of there being 9 Socialist senators there would be 18, and you [the Conservatives] would be reduced to 2 or 3 ... [laughter] you laugh, but the truth is that there would be not 2 Conservative senators from O'Higgins and Colchagua, which corresponds exactly to the number of inquilinos in the fundos which belong to the Conservative hacendados in that region. Conservatives would have only one or perhaps none." ${ }^{7}$

We develop a model of labor contracting with moral hazard and limited liability in the rural sector. ${ }^{8}$ Absent politics, landlords find it optimal to concede rents

\footnotetext{
${ }^{5}$ For evidence from India see Kohli (1990, pp. 227-228) and Breman (1974).

${ }^{6}$ See Engerman and Sokoloff (2005) and Hartlyn and Valenzuela (1998). For Brazil see Pang (1973), Graham (1990) and Martins (1996).

${ }^{7} \mathrm{~A}$ "fundo" is a large farm and a "hacendado" a large landowner and an inquilino was a permanent worker on such farms. Quoted in El Mercurio, Saturday May 19, 1958, p. 20.

${ }^{8}$ Why does electoral corruption seem to be more significant in rural as opposed to urban areas? Our model suggests three factors which indicate that urban votes may be more expensive to buy and hence political corruption relatively less attractive in urban settings. First, as suggested by Marglin (1973) it may be the case that rents are lower in factories and urban environments. This means that, to induce effort, employers need to pay only a small wage premium. Second, it may be harder to monitor voting and political activities in anonymous urban environments.
} 
to workers to induce effort. Introducing politics, we show that the presence of these rents allows landlords to pay less than the full opportunity cost of the votes of their workers, and thus possibly to profitably offer a contract stipulating both economic and political (voting) behavior. ${ }^{9}$ This feature also implies that it is cheaper for political parties to buy votes indirectly through landlords since this means they can avoid fully compensating workers for the value of their votes. We study the implications of these phenomena for the functioning of factor markets.

The model we develop generates predictions about electoral outcomes which can be tested by investigating the impact of the introduction of an effective secret ballot. Such an institutional reform reduces landlords' control, and in consequence, we should observe changes in voting behavior, since workers whose votes were previously controlled and sold can now vote freely.

We examine these implications by considering the introduction of the secret ballot in 1958 in Chile. We show in section 4 that the empirical predictions of our model are highly consistent with the data. We first demonstrate that before 1958 control of voting was endemic in the traditional 'oligarchic' provinces of the so-called North and Urban Central Valley provinces which were characterized by long term patron-client relationships known in Chile as the inquilinaje system (see e.g. Sadoulet, 1992). More precisely, we show that, before the reform, the support for right-wing parties was substantially higher, but that it also fell substantially more thereafter in precisely those municipalities where inquilinos formed a larger share of the electorate.

The case study literature on the secret ballot focuses very much on coercion and corruption and has obviously noticed the fact that systematic biases can be introduced into elections because of such phenomena (e.g., our discussion of nineteenth century Germany above). In the Chilean case, scholars such as Loveman (1976), Scully (1992) or Bauer (1995), have noted the significance of the control of inquilinos for the political power of the right before 1958, and linked the intro-

Third, workers in the cities may enjoy superior alternative employment opportunities, which reduce the scope for political control by their employers.

${ }^{9}$ Though we model political control in terms of voting, the analysis extends to other types of political activities (such as types of protests, riots, demonstrations and other forms of collective action). Such a model would have similar results to the one we present. 
duction of the secret ballot to the rise of socialism. Our contribution here is to provide a microfoundation for why landlords control voting behavior and provide the first systematic test of the impact of the 1958 reforms in Chile.

The incidence of secret balloting has been understudied by the literature on political economy and institutions (e.g., Cox, 1997, Persson and Tabellini, 2000, 2003, Acemoglu and Robinson, 2006). Piketty (1999, 2000) and Dekel, Jackson and Wolinsky (2004) developed models of how an individualized market for votes might work and have studied the circumstances under which vote buying is socially undesirable. Related papers by Snyder (1991) and Grossman and Helpman (1996) have looked at interest groups buying politicians with 'campaign contributions.' All of these theoretical papers focus on very different issues than those we study. An important distinction is that these scholars, and most others in the political economy literature, focus on the efficiency of government policy. We focus on why vote buying is linked to employment and how this influences factor markets. We also provide empirical evidence supporting our model. Most closely related to our research, Summerhill (1995) developed a simple model of the idea that political rents accrue to landowners and tried to estimate the impact of electoral reform on the economy using data from nineteenth century Brazil.

\section{The Model}

\subsection{The Fundamentals}

We consider a discrete time infinite horizon model of the rural sector. There is a unit mass of agents and a proportion $x$ of rural agents have access to the capital market and can therefore purchase land and hire workers. All rural agents have the option to be self-employed and earn an income of $\underline{w}$. We let $m$ denote the proportion of rural agents who become agricultural workers, and $1-m-x$ those who remain self-employed.

There are $L$ units of land which are owned by landowners with each owning $L / x=l$ units of land. There is a single numeraire consumption good which is

produced from land and labor. The technology is characterized by a standard 
constant returns to scale neoclassical production function. On a farm, output of a worker in any period is equal to $\tilde{\theta} g\left(\frac{l}{n}\right)$ where $n$ is employment, $g$ is the intensive form of the production function so that $g^{\prime}>0$ and $g^{\prime \prime}<0$, and $\tilde{\theta}$ is a plot-specific stochastic shock to output which is distributed independently across plots and time and can take two values, $\theta$ and 0 (by normalization) (since we focus on stationary equilibria we do not introduce time subscripts). The probability that $\theta$ occurs in period $t$ depends on the effort exerted by a worker in that period. ${ }^{10}$ Effort, $\varepsilon$, takes two values, $\varepsilon \in\{0, e\}$. If $\varepsilon=e, \theta$ occurs with probability $\gamma^{h}$, while if $\varepsilon=0, \theta$ occurs with probability $\gamma^{l}<\gamma^{h}$.

While output is perfectly observable by the landlord, the level of effort exerted by the worker is not. This induces a moral hazard problem. We assume that effort can never be observed so that the only possible wage contract depends on the realization of $\tilde{\theta}$.

There are also two political parties, 'Left' (denoted $L$ ) and 'Right' (denoted $R$ ) competing for votes to win an election and all individuals have exogenous preferences for one of these parties which means that they get utility from voting for the party they prefer (as in a standard probabilistic voting model).

All agents in the rural sector have utility functions which are linear in consumption, $c$, effort, $\varepsilon$, and voting decision $\sigma^{j}$ for $j=L, R$ which depends on the ideological orientation of the agent. Thus, $U\left(c, \varepsilon, \sigma^{j}\right)=c-\varepsilon+\sigma^{j}$ is the utility of an agent of type $j$ if they vote for the party they prefer, otherwise it is $U\left(c, \varepsilon, \sigma^{j}\right)=c-\varepsilon$. All agents maximize the expected present discounted value of utility and discount the future at rate $\beta \in(0,1)$.

Political party $j$, if it wins power, has per-period utility function,

$$
U_{j}=W^{j}-M_{j}, j=R, L
$$

and $-M_{j}$ otherwise, where $W^{j}$ is the gain in utility for party $j$ if it wins the election and $M_{j}$ represents the amount of rents (income) transferred by party $j$ to other agents in the economy so that neither party is liquidity constrained. The price that a party offers for the vote of an agent will in general depend on the

\footnotetext{
${ }^{10}$ We use a variant of a model which has become standard in the development literature, see for example Banerjee, Gertler and Ghatak (2002)
} 
occupation of the agent: let $p_{\ell}^{j}$ be the price paid by party $j$ to a landlord, $p_{w}^{j}$ be the price paid by party $j$ for the vote of a worker, and $p_{s}^{j}$ be the price paid for the vote of a self-employed agent. ${ }^{11}$ Let $\mu$ be the impact of one vote in party $j$ 's favor on party $j$ 's chances of winning the election. ${ }^{12}$ From this we can deduce that the maximal price that party $j$ would be prepared to pay for a vote is $\mu W^{j}$.

\subsection{Timing of the stage game}

The stage game has the following timing:

- The political parties non-cooperatively announce a price at which they will purchase votes from each type of rural agent.

- The land market opens with each landlord deciding how much land to buy.

- Landowners hire workers by proposing a contract.

- Agents sell votes to the political parties.

- Workers vote and choose their effort level.

- Production take place and the output shock $\tilde{\theta}$ is observed.

- Landlords and the political parties observe voting behavior and the state of nature.

- Rents are distributed by the political parties, wages are paid and workers may be fired and consumption takes place.

We now characterize the stationary subgame perfect equilibrium of this game.

\footnotetext{
${ }^{11}$ Though we focus our analysis on situations where political parties directly purchase votes, the model is consistent with other interpretations. For example, instead of buying votes, parties may offer policies which favor landlords, or give landlords elected positions.

${ }^{12}$ In a previous version of the paper we provided microfoundations for this assumption with an explicit model of voting under proportional representation and legislative bargaining (see Austen-Smith, 2000, and Baron and Deirmeier, 2001).
} 


\section{Electoral Corruption and Resource Allocation}

For ease of exposition we first characterize the outcome of political competition for votes. We do so by assuming, as will be the interesting case, that landlords control and sell the votes of their workers. In the next section we analyze the circumstances under which this will happen in equilibrium. To keep the discussion focused we assume that all landowners are right-wing while all other agents are left-wing. In addition we assume that the right-wing party values winning more than the left-wing party. This will have the implication that the right-wing party will be prepared to pay more for votes than the left-wing party.

The political parties engage in Bertrand competition. We first consider the situation in which the right-wing party will always wish to outbid the left-wing party for votes. This implies that $\mu W^{R} \geq \mu W^{L}+\sigma^{L}$ and the following prices are offered by the parties in equilibrium,

$$
\text { Party } R \text { offers }\left\{\begin{array}{c}
p_{\ell}^{R}=\mu W^{L}-\sigma^{R} \\
p_{w}^{R}=\mu W^{L} \\
p_{s}^{R}=\mu W^{L}+\sigma^{L}
\end{array}\right.
$$

and,

$$
\text { Party } L \text { offers } p_{\ell}^{L}=p_{w}^{L}=p_{s}^{L}=\mu W^{L}
$$

In this case, for any price that the left-wing party proposes for votes, the rightwing party is always willing to outbid that offer for the three categories of rural agents. As a result, in equilibrium, the left-wing party announces the maximal

price it is ready to pay for one vote, $\mu W^{L}$. Given this price, landlords will be willing to sell their own votes to the right-wing party provided they can achieve the same utility level that they could by selling their votes to the left-wing party. This implies that the right-wing party must offer them a price at least equal to $p_{\ell}^{R}=\mu W^{L}-\sigma^{R}$. Landlords will also sell the votes of their workers if they are given the same price that is offered by the left-wing party, which is then the price the right-wing party announces. Lastly, for the self-employed agents, the right-wing party must compensate them for not voting for their own preferred party, which implies that he has to pay a price $p_{s}^{R}=\mu W^{L}+\sigma^{L}$ to those agents. 
Given these prices, all rural agents sell their votes to the right-wing party, with right-wing landlords stipulating that their left-wing workers vote right-wing in their employment voting contracts.

In the case where $\mu W^{L}+\sigma^{L} \geq \mu W^{R}>\mu W^{L}$, then

$$
\text { Party } R \text { offers }\left\{\begin{array}{c}
p_{\ell}^{R}=\mu W^{L}-\sigma^{R}, \\
p_{w}^{R}=\mu W^{L}, \\
p_{s}^{R}=\mu W^{R},
\end{array}\right.
$$

and,

$$
\text { Party } L \text { offers }\left\{\begin{array}{c}
p_{\ell}^{L}=\mu W^{L}, \\
p_{w}^{L}=\mu W^{L}, \\
p_{s}^{L}=\mu W^{R}-\sigma^{L} .
\end{array}\right.
$$

It is no longer optimal for the right-wing party to outbid the left-wing party for the votes of the self-employed agents. Now, rather than buying the votes of all rural agents, the right-wing party buys the votes of the landlords and their workers, but the self-employed sell their votes to the left-wing party. Here, moving from being self-employed to becoming a worker leads to a switch in voting behavior.

Under either scenario we have the following result.

Proposition 3.1. It is cheaper for the right-wing party to buy votes from a landlord than to buy votes directly from the self-employed.

This result follows immediately from the fact that in equilibrium $p_{w}^{R}<p_{s}^{R}$. This proposition has the implication that it will never be profitable for a rural agent to become a political entrepreneur, buying votes from individuals and then selling them to parties. For the rest of the paper we focus on the situation where $\mu W^{R} \geq \mu W^{L}+\sigma^{L}$, the analysis of the other parts of the parameter space follow directly.

\section{Employment and Power}

We solve for the stationary subgame perfect equilibrium of this game which is best from the point of view of landlords. In general a strategy for a landlord is a 
contract offer at date $t$ which specifies wages as a function of $\tilde{\theta}$, a voting decision and the history of play up to $t$. For a worker a strategy determines an effort and voting decision as a function of the history and the contract offered at $t$.

We start by describing the optimal labor-voting contract. As is standard, we endow the landlord with all the bargaining power with respect to workers and he can therefore make take-it-or-leave-it contract offers to his worker(s) specifying his expected voting behavior and effort level. As there are two dimensions to the worker's behavior, there are four possible wages, corresponding to whether output is high or low, and whether the worker is observed voting for the specified party or not. We assume that liability is limited so that wages must be non-negative. To ensure maximal incentives, a landlord will optimally propose a wage, $w$, and continued employment if output is high and the worker is not observed voting for the wrong party. If output is low or the worker votes for the left-wing party, the landlord will pay zero and fire the worker. We assume that if a worker is ever fired by a landlord he is never employed again by a landlord and is thus perpetually self-employed.

We focus here on the situation under which a worker is required by his landlord to vote for the right-wing party. Given his voting behavior, the worker will exert the optimal amount of effort if the following incentive compatibility condition is satisfied. Let $V_{w}(\varepsilon=e)$ be the value to the worker if he exerts effort, while $V_{w}(\varepsilon=0)$ is the value if the worker shirks. The worker will exert effort if

$$
V_{w}(\varepsilon=e) \geq V_{w}(\varepsilon=0)
$$

First consider the value from exerting effort which is,

$$
V_{w}(\varepsilon=e)=\gamma^{h}\left(w+\beta V_{w}(\varepsilon=e)\right)+\left(1-\gamma^{h}\right)\left(\frac{\beta\left(\underline{w}+\mu W^{L}+\sigma^{L}\right)}{1-\beta}\right)-e .
$$

Here, with probability $\gamma^{h}$ the realization of output is high, in which case at date $t$ the worker receives the wage $w$ and is not fired. In consequence the worker gets the continuation value $\beta V_{w}(\varepsilon=e)$. With probability $1-\gamma^{h}$, even though the worker exerted effort, output is low. In this case the worker gets no wage and 
is fired at date $t$, never to be re-employed. In this case from date $t+1 \mathrm{on}$, the worker is self-employed getting an income of $\underline{w}$ in each period and also being able to freely sell his vote to whichever party he wishes. The utility from this latter action is $\max \left\{p_{s}^{R}, \sigma^{L}+p_{s}^{L}\right\}$, i.e. the self-employed agent can sell his vote to the right wing party and sacrifice the utility benefit of voting for his preferred party, or he can sell his vote to the left and get the utility benefit $\sigma^{L}$. Now in equilibrium we showed that $p_{s}^{R} \equiv \sigma^{L}+p_{s}^{L} \equiv \mu W^{L}+\sigma^{L}$ and this explains the formula in (4.1). We now consider the value of shirking, which is

$$
V_{w}(\varepsilon=0)=\gamma^{l}\left(w+\beta V_{w}(\varepsilon=0)\right)+\left(1-\gamma^{l}\right)\left(\frac{\beta\left(\underline{w}+\mu W^{L}+\sigma^{L}\right)}{1-\beta}\right)
$$

The interpretation of (4.2) follows immediately from the discussion of (4.1), noting that now, since the worker is shirking, he does not incur any effort cost and high output arises with probability $\gamma^{l}$. Hence, solving for the value functions, exerting effort is optimal if

$$
w \geq \beta\left(\underline{w}+\mu W^{L}+\sigma^{L}\right)+\frac{\left(1-\beta \gamma^{l}\right)}{\gamma^{h}-\gamma^{l}} e
$$

Next there is the participation constraint which shows that the worker prefers accepting a contract to his outside option. This implies

$$
V_{w}(\varepsilon=e) \geq \frac{\underline{w}+\mu W^{L}+\sigma^{L}}{1-\beta} \text { or } w \geq \frac{\underline{w}+\mu W^{L}+\sigma^{L}+e}{\gamma^{h}} .
$$

The two constraints are sufficient to define a contract eliciting high effort and voting behavior that will be accepted by a worker. Indeed, if this contract is offered, the worker never chooses to vote against his landlord's wishes (whether with high or low effort), as this implies with certainty his getting a zero wage and being fired. This yields a utility to the worker that lies below his reservation utility, so that, ex ante, the worker is better off not accepting this contract. As a result, accepting the contract but voting freely is never chosen in equilibrium. Therefore, the only relevant constraints to the landlord's problem are (4.3) and (4.4). Note also that, to be optimal from the landlord's point of view, the contract must be such that one of these two constraints holds with equality. 
We now explicitly define the labour rents that are attributable to the existence of a moral hazard problem in production. To do this, we consider the wage rate that would be offered by the landlord in a contract that stipulates the effort level, but not the voting behavior. In this contract, the efficiency wage under the incentive compatibility constraint would be

$$
\tilde{w}=\beta \underline{w}+\frac{\left(1-\beta \gamma^{l}\right)}{\gamma^{h}-\gamma^{l}} e .
$$

We consider the situation under which, with this contract, the participation constraint is satisfied, that is:

$$
\tilde{w} \geq \frac{\underline{w}+e}{\gamma^{h}} .
$$

Moreover, to simplify the exposition, we assume that it is optimal to propose this contract which induces high effort by paying an efficiency wage even if it concedes rents to workers. We define $r$ as the per period excess in expected utility compared to the reservation utility, that is the per period labour rent under the incentive contract:

$$
r=\gamma^{h} \tilde{w}-e-\underline{w}=\left(\frac{\gamma^{l}}{\gamma^{h}-\gamma^{l}} e-\underline{w}\right)\left(1-\beta \gamma^{h}\right),
$$

by using equation (4.5). We next define $R$ as the present discounted value of labour rents:

$$
R=r+\beta \gamma^{h} r+\left(\beta \gamma^{h}\right)^{2} r+\ldots=\frac{r}{1-\beta \gamma^{h}}=\frac{\gamma^{l}}{\gamma^{h}-\gamma^{l}} e-\underline{w}
$$

As can be inferred from condition (4.6), the participation constraint is satisfied if and only if $R>0$ under the efficiency wage.

We need one more assumption before stating our main result.

Assumption 1: $\mu W^{L}>\gamma^{h} \beta \sigma^{L} /\left(1-\gamma^{h} \beta\right)$.

Assumption 1, which comes from $\mu W^{L}>\gamma^{h} \beta\left(\mu W^{L}+\sigma^{L}\right)$, says that the value of a vote to the landlord must be large, relative to the ideological bias of the worker.

Proposition 4.1. It is optimal for the landlord to also control the political behavior of his worker if and only if $R>\sigma^{L}$. 
Proof. First note that if the wage had to be increased by the full disutility of voting behavior being controlled, namely $\mu W^{L}+\sigma^{L}$, then it could never be profitable for the landlord to offer a contract which controlled voting. This is because expected output would be the same but a vote can only be sold for $\mu W^{L}$.

The wage that has to be paid to deter cheating when the landlord decides to also control voting behavior must satisfy (4.3). Using (4.5), we can write:

$$
w-\tilde{w} \geq \beta\left(\mu W^{L}+\sigma^{L}\right)
$$

This wage has also to satisfy the participation constraint (4.4) and, using (4.6), we obtain:

$$
w-\tilde{w} \geq \frac{\mu W^{L}+\sigma^{L}}{\gamma^{h}}-\frac{R}{\gamma^{h}} .
$$

Given that the contract must be optimal, one of those two conditions holds with equality. First consider the case where (4.7) holds with equality. Paying this wage is then profitable for the landlord if the expected increase in the wage is less than the benefit from controlling a vote $\mu W^{L}$, i.e.:

$$
\mu W^{L} \geq \gamma^{h}(w-\tilde{w}) \geq \gamma^{h} \beta\left(\mu W^{L}+\sigma^{L}\right)
$$

which holds by assumption. Consider the situation such that the participation constraint is binding, so that (4.8) holds with equality. Paying this wage is profitable to the landlord if :

$$
\mu W^{L} \geq \gamma^{h}(w-\tilde{w}) \geq \mu W^{L}+\sigma^{L}-R,
$$

which holds if and only if $R>\sigma^{L}$.

Intuitively, the simple fact that the labor market is plagued by moral hazard and that liability is limited implies that the landlord must concede rents to his workers. This occurs even though he is in a position to make take-it or leave-it offers to the latter. As long as the rents exceed the ideological bias, the increase in wages landlords must concede to their workers in order to also control their voting behaviour is lower than the price they receive for these votes from the parties. ${ }^{13}$

\footnotetext{
${ }^{13}$ The surplus thus given to the workers also yields a comparative advantage to the employer in other spheres, such as the credit market. This argument has been used in part of the literature on interlinked contracts.
} 
It is interesting to observe that if workers are unideological, so that $\sigma^{L}=0$, as long as the political parties attach a positive value to votes and there are rents, Proposition 2 follows without any other assumptions. Note, however, in this case, equilibrium the price paid by the right-wing party for the vote of any rural agent is identical and therefore it is no longer true that it is strictly cheaper to buy votes through landlords.

We now have to consider whether it is optimal for landlords to pay the efficiency wage $w^{*}$ which satisfies both (4.3) and (4.4) with at least one equality. To understand this we first consider the optimal demand for labor in a farm of size $l$ with $n$ workers. Profits are,

$$
\gamma^{h} \theta g\left(\frac{l}{n}\right) n-\gamma^{h} w^{*} n+\mu W^{L} n
$$

The first term in (4.9) is expected revenues, the second the expected wage bill, and the third the political rents that the landlord gets from selling the votes of his $n$ workers at the price $\mu W^{L}$. The optimal demand for labor is determined by the first-order condition,

$$
\gamma^{h} \theta\left(g\left(\frac{l}{n}\right)-g^{\prime}\left(\frac{l}{n}\right) \frac{l}{n}\right)-\gamma^{h} w^{*}+\mu W^{L}=0
$$

The equation (4.10) implicitly defines the optimal demand for labor as a function of parameters, which we write $n\left(l, \mu W^{L}, w^{*}\right)$.

It is always profitable for the landlord to pay this efficiency wage contract if

$$
\left(\gamma^{h}-\gamma^{l}\right) \theta g\left(\frac{l}{n\left(l, \mu W^{L}, w^{*}\right)}\right)+\mu W^{L} \geq \gamma^{h} w^{*}-\underline{w}
$$

We therefore assume that the expected increase in profit from workers exerting effort, evaluated at the efficiency wage, plus the rents from selling their votes must be greater than the expected increase in the wage bill.

The model has interesting implications for the price of land, denoted $\pi$. In the model landlords hold land while workers have no access to capital markets and cannot purchase land. Nevertheless, landlords could buy land from each other. 
The equilibrium price of a plot of land must now adjust so that profits are zero or,

$$
\left(\gamma^{h} \theta g\left(\frac{l}{n\left(l, \mu W^{L}, w^{*}\right)}\right)-\gamma^{h} w^{*}+\mu W^{L}\right) \frac{n\left(l, \mu W^{L}, w^{*}\right)}{l}=\pi
$$

Equation (4.12) implies the following result.

Proposition 4.2. In equilibrium the price of land incorporates political rents.

Acquiring land is desirable not only for productive purposes, but also for the political rents attached to the political control of the workforce employed on it. Equilibrium prices on the land market reflect this mechanism.

It follows from Proposition 4.2 that a political reform which stops landlords controlling the political behavior of their workers, such as the introduction of an effective secret ballot, removes the ability of landlords to sell their votes and has interesting comparative static effects.

Proposition 4.3. The introduction of a secret ballot leads to a fall in the price of land and the vote share of the right-wing party.

If all agents had access to capital markets then there would be no land concentration and all land would be farmed by smallholders with no workers getting rents. The fact that, with perfect capital markets, smallholders are always willing to outbid landowners for land follows from the fact that, through the participation constraint, the economic rents that landlords transfer to workers exceed the political rents they receive from parties. Therefore, even though it is still true that the ability of landlords to sell votes increases their demand for land, land is still more valuable to smallholders. ${ }^{14}$

The interaction of the market failures is crucial. Without moral hazard there are no rents and even with imperfect capital markets electoral corruption would not affect the price of land, as workers would then have to be fully compensated for the control of their votes. At the same time, with moral hazard but no capital market imperfections there is no inefficiency either.

\footnotetext{
${ }^{14}$ The inefficiency here stemming from imperfections in the capital market is related to the results of Banerjee and Newman (1993), Legros and Newman (1996), Mookherjee (1997) and Banerjee, Gertler and Ghatak (2002)
} 


\section{A Study of Land and Power: Chile}

\subsection{The political impact of the 1958 electoral reform: an overview}

Like most Latin American countries, upon gaining independence from Spain, Chile adopted republican institutions. These became institutionalized in the 19th century and elections determined presidential succession without military or other intervention. Universal literate male suffrage was introduced in 1874 but voting was not secret. Interestingly, the 1874 suffrage extension in Chile was opposed by some more progressive Chileans as they "fully realized that in a predominantly rural society with traditional landlord-peasant ties, the Conservatives would overwhelm their opponents at the polls." (J. Samuel Valenzuela, 1985, see also Bauer, 1995, p. 30). The nineteenth century democracy collapsed in 1924 and the following period saw five military coups before democracy was restored in 1932. The intervening period was dominated by Colonel Carlos Ibáñez. After 1932 democratic stability was based on an explicit compromise between the growing power of urban groups and the power of the traditional landed elites. ${ }^{15}$

\subsubsection{Mechanisms of Control of Rural Votes}

"Throughout the history of the Republic, the political influence of the rural sector in Chile was disproportionately greater than its size relative to the urban sector. Congressional representation was heavily weighted in favor of rural districts where the peasantry historically formed a pliable and controllable mass base for conservative and reactionary groups" (Hellinger, 1978, p. 272). Landlords systematically controlled rural voting until the late 1950s. There is a consensus amongst historians, political scientists and sociologists about how this system functioned (see Kaufman, 1972, Bauer, 1975, Loveman, 1976, Petras and Zeitlin, 1968, and Scully, 1992, ch. 4): "There was an absolute control of peasants by their patrones, and elections in rural communes depended on the political preferences of the landowners" (Millar, 1981, p. 172). Large landlords usually registered all

\footnotetext{
${ }^{15}$ The Chilean pact is discussed in more detail in Valenzuela (1978), Collier and Collier (1991, pp. 565-73) and Scully (1992, pp. 108-109).
} 
their employees, by teaching them how to sign their names (as literacy was a condition for vote registration). The day of the election, the employer would go vote with all their employees. "This type of control is pervasive ... The situation was publicly accepted, and it was even used as an argument in electoral legal complaints, particularly in order to show that any result against the preferences of the latifundistas was fraudulent, or to justify an unanimous electoral result in a rural locality" (Millar, 1981, p. 173). Part of the political pact which developed after the 1930s also involved the banning of agricultural unions, a policy which allowed severe labor repression to be carried on in the countryside, often backed by the police (Bauer, 1995, p.32).

In line with our model, the control of rural votes by landlords was made possible by the relatively good working conditions of the inquilinos compared to the possible alternatives: "They were free ... but they had no defence in the face of expulsion; indeed, the threat of being cast out into the subproletariat of migratory workers was the most powerful weapon at the landowner's disposal. Most inquilinos families undoubtedly judged their welfare on the estate superior to life outside or in the nitrate fields of the northern desert." (Bauer, 1995, p. 28). The patron-client relationship was very developed (see in particular Bauer, 1995). Thus, "anyone seen visiting the home of a resident laborer would be immediately approached and questioned by the owner, who reserved the right to expel him from the property" (Swift, 1971, p. 37).

\subsubsection{The political equilibrium in the $1950 \mathrm{~s}$}

By the 1950s the political landscape in Chile was dominated by several main parties. There were the traditional nineteenth century parties, the Conservatives, Liberals and Radicals. The Conservatives and Liberals were furthest to the right and united in most things except in their attitudes to the Church (the Conservatives were closely associated with the Catholic Church). The Radicals were more towards the center politically and were strongly anti-clerical. Also in the center, though small in the 1950s, were the Christian Democrats. To the left were the

Socialists and then the Communists (the latter were officially banned between 
1948 and 1958 though they competed under different names). The landed oligarchy provided the traditional constituency of the two right-wing parties, the Conservative and the Liberal (see, e.g., Gil, 1966 and Sinding, 1972). The existing party system was shocked however by the return from exile of the former dictator Carlos Ibáñez as a populist presidential candidate in 1952. Ibáñez formed a very heterogenous coalition of mostly leftist groups and capitalized on the general disillusionment with the traditional parties.

Chilean electoral institutions in this period were based upon the D'Hondt system of proportional representation for all elections, under the 1925 Constitution (for more details, see Gil, 1966, Chapter 5, and Morodo, 1968). The constituencies broadly coincided with the boundaries of Chile's provinces. Deputies were elected for four year terms, senators for eight with half of the Senate being replaced every four years. Prior to the reforms of 1958, parties issued their own ballot papers and a closed list system was used. Thus to vote for the Socialist party, a voter had to request the Socialist ballot which made it relatively easy to determine his voting behavior. ${ }^{16}$ Until 1951 only literate males over the age of twenty-one could vote; of those eligible to vote, approximately 50 percent usually registered, and the vast majority of those registered cast ballots. Women were allowed to exercise the franchise in installments, first for municipal elections in 1935, then for congressional contests in 1951, and finally for presidential races in $1952 .{ }^{17}$

\subsubsection{The introduction of the secret ballot in 1958}

There were several important electoral reforms undertaken in Chile in the late 1950s and early 1960s. The most important was Law 12.889 promulgated on May 31st 1958, amending the basic electoral law of 1925 (see Castro, 1941, p. 35 and Cruz Coke, 1984, pp. 27-29 for a discussion of this law) and its most important aspect was the introduction of the cédula única (the unified ballot). After 1958, the voter received a single, official ballot, which contained all party slates for

\footnotetext{
${ }^{16}$ Loveman (2001, pp. 222-3) provides a detailed discussion of how party provision of ballots before 1958 facilitated electoral corruption.

${ }^{17}$ Note that registration and vote turn-out are very close in Chile, since once an individual registers, voting is mandatory.
} 
any single type of election in his district and an open list system was adopted so that voters did not have to respect any official ordering of candidates. Another important law of 1958 banned electoral pacts between parties for deputies and councilmen (a 1962 electoral law extended this prohibition to senatorial elections).

The introduction of the secret ballot had an immediate impact on the balance of political power in Chile. Loveman (1976, p. 219) notes, "The introduction of a public ballot meant that landowners could no longer effectively control the votes of rural labor. The electoral hegemony of the Right in the countryside thus gave way to forces that advocated social change in the rural areas ... In 1958 the performance of the FRAP (Socialists and Communists) in rural districts left little doubt that landowners' control over rural votes had considerably declined."

If the lack of secret balloting had played an important role in guaranteeing democratic stability in Chile since the 1930s, why was the secret ballot introduced in 1958? Though this issue appears not to have been researched by political scientists, the most plausible reason for this is a deliberate attempt to disrupt the existing political equilibrium. As we noted above, the election of Ibáñez in 1952 was based on a heterogenous coalition and an 'anti-politics' platform. ${ }^{18}$ Ibáñez intended to forge a new political movement and though he failed in this, it seems likely that the introduction of the secret ballot, with its easily anticipated effects on voting in the countryside, was a calculated gamble. It may also have been part of a deal which he made with some of his key supporters, the Agrarian Labor party (Agrario Laboristas) and the Popular Socialist party (Partido Socialista Popular) both of which would have had an interest in mobilizing rural voters.

Interestingly however, despite these changes, the Conservative Jorge Alessandri won the presidential election in 1958, principally on a platform emphasizing conservative monetary policies which were a response to the populism of the Ibáñez regime. ${ }^{19}$ Under Ibáñez per-capita GDP had fallen by $2 \%$ and inflation had averaged $45 \%$, peaking at an annual rate of $76 \%$ in 1955 (see Ffrench-Davis,

\footnotetext{
${ }^{18}$ His campaign was based on the symbol of a "broom" with which he promised to "sweep" away political corruption and bad governments...

${ }^{19}$ Though he polled only 33,416 votes (out of 1,235,552 cast) more than Salvador Allende, the candidate for the Socialist and Communist alliance. Antonio Zamorano, a leftist defrocked priest, deprived Allende of a victory by gaining 41,304 (3.3\%) left-wing votes.
} 
1973, p. 242 and Table 35). However, the right began to disintegrate during the 1960s with the rise of the centrist Christian Democratic Party (Partido Demócrata Cristiano-PDC), founded in 1957 with the merger of three conservative elements: the National Falange, founded in 1938; the Social Christian Conservative Party; and the remnants of the Agrarian Labor Party that had backed Ibáñez. In the 1960s, the Christian Democrats became more progressive, and espoused reformist Catholic doctrines, which appealed strongly to the middle class, women and rural voters. In 1966 the Conservatives and Liberals merged to form the National Party. The Christian Democrat candidate, Eduardo Frei, won the presidency in 1964, and in 1970 the Christian Democrats provided support to Allende, in exchange of his guaranteeing strict adherence to democratic procedures.

\subsection{Agrarian relations and electoral results across provinces}

We collected data from the 1957, 1961 and 1965 electoral registries, the agricultural census of 1935, 1955 and 1965 (see the Appendix) and the population censuses of 1930 and 1940. The data were collected at the communa (municipality) level, which corresponds to the lowest level of electoral district as well as the smallest administrative unit. As census units do not always strictly match the electoral districts, and changed definition over time, we had to exclude all the communas for which we could not be certain of the correspondence, which left us with a sample of 246 communas (out of 295). (This also explains why we do not use data over a longer interval of time.) The main variables used throughout the analysis are described in the Appendix (table A1).

We focus on the 1957 parliamentary (all of the congress and half of the senate) elections, as it allows a more direct comparison to the parliamentary elections that occurred after 1958, and in particular the 1961 and 1965 elections. ${ }^{20}$ We describe

\footnotetext{
${ }^{20}$ We do not take the 1953 congressional and senatorial elections because they were very exceptional. After the election to the presidency of Carlos Ibáñez in 1952, the 1953 elections saw a transient collapse in the right-wing vote in the face of the Ibáñista bandwagon. Scully (1992, p. 126) notes "The disruption of familiar patterns of party competition was also reflected in the extreme fragmentation by the party system in the congressional elections of 1953. In that year, 25 party organizations presented candidates, and 19 achieved representation. Party proliferation weakened Chile's traditional parties. Whereas in the congressional elections of 1949
} 
in Table 1 the main trends at the level of the provinces. In the table, we report the information over the three Central Valley regions, its two neighboring regions, the Frontier and the Little North, and the other regions.

\section{INSERT TABLE 1 HERE}

The relationship between agrarian relations and electoral outcomes is striking. In 1957, the landed oligarchy in Chile dominated the Urban and the North Central Valley provinces: the proportion of inquilinos in the number of registered voters in 1957 is 18.9 percent in the North Central Valley, and 17.2 in the Urban Central Valley, but 11.2 in the Frontier and Little North, and 8.2 in the other provinces. Unsurprisingly, the share of right-wing votes in 1957 in the North Central Valley was 50.0 percent, and 40.8 percent in the Urban Central Valley, much higher than in the other provinces. ${ }^{21}$

After 1958, the fall in the right-wing votes occurs in provinces with a larger proportion of inquilinos per worker (across provinces, the correlation coefficient between the two is equal to -0.67). The fall in right-wing votes is dramatic in the Central Valley provinces. Even the absolute number of right-wing votes fell in those areas, in spite of an increase in registered voters. The fall is very pronounced in some provinces, such as Colchagua (-48.1\%) from an absolute majority of $70.2 \%$ of the votes in 1957 to barely $22.5 \%$ in $1965 .{ }^{22}$

the Conservative, Liberal, and Radical parties combined received more than $60 \%$ of the vote, in 1953 they received barely on third." This was just a temporary phenomena however. Scully goes on to add (1992, p. 126) "Though Ibáñez had put the leadership of traditional parties on the defensive in 1953, the situation was reversed between 1953 and 1957." Focusing on 1953 therefore has a tendency to underestimate the fall in conservative support after 1958. Moreover the definition of electoral circonscriptions changed through time, which would further restrict our sample.

${ }^{21}$ The relationship between right-wing votes in the 1957 elections and land concentration is less clear however. This is due to the fact that in the arid, semi-arid and infertile provinces to the north and to the south of the Central Valley (including the Frontier), land concentration tends also to be high, as a result of the technological constraints on agriculture in these provinces (ranching instead of farming).

${ }^{22}$ Hellinger (1978) analyzed electoral change in the Chilean countryside for the two presidential elections of 1958 and 1970, based on correlations from a restricted (and biased) sample of municipalities. He points out the gradual erosion of support for the Right as the correlation between the vote for the Nationalists as the proportion of inquilinos in the agricultural workforce fell. He however fails to provide a consistent explanation for this change in rural voting pattern. 


\subsection{The political impact of the 1958 electoral reform: a test}

\subsubsection{The empirical strategy}

The empirical strategy pursued in this paper can be described as follows. Before the 1958 reform, the share of right-wing votes should be higher in communas with more inquilinos since their votes are then controlled. However, after the reform, the influence of inquilinos on electoral results should disappear, so that the difference in voting patterns across the two types of communas should disappear. In table 2 below, we report the electoral results in 1957 and 1965 for communas with less and more inquilinos than the median.

\section{INSERT TABLE 2 HERE}

Over the period, right-wing votes in communas with less inquilinos fell by $16.2 \%$ while it fell by $-30.3 \%$ in communas with more inquilinos. The impact of the loss of control over inquilinos votes on the fall in right-wing votes corresponds to the difference between these two figures, $-14.1 \%$. The model below aims at estimating this impact more precisely.

In Figure 1, we present simple OLS scatter plot of the relationship between right-wing votes and the proportion of inquilinos in each communa. The pattern is striking, as the impact of inquilinos on right-wing votes is significantly diminished after 1958.

\section{INSERT FIGURE 1 HERE}

\subsubsection{The empirical models}

We now present the model used in the empirical analysis. We let $R V_{i, t}$ represent the number of votes cast in favor of the right-wing party, $V_{i, t}$, the total number of voters, and $V_{i, t}^{h}$, the total number of voters of type $h$ at time $t$ in communa $i$. Voters can be of three different types: $h=i n q$ if the voter is an inquilino, $h=a g r$ if the voter is not an inquilino but works in agriculture, and $h=n a$ if he is not an agricultural worker. We can then write:

$$
R V_{i, t}=\left(\theta_{i}+\rho_{I, t}+\tau_{t}^{i n q}\right) V_{i, t}^{i n q}+\left(\theta_{i}+\rho_{I, t}+\tau_{t}^{a g r}\right) V_{i, t}^{a g r}+\left(\theta_{i}+\rho_{I, t}+\tau_{t}^{n a}\right) V_{i, t}^{n a}+\varepsilon_{i, t} V_{i, t}
$$


where $\theta_{i}$ is a communa specific fixed effect, which represents the time-invariant propensity to vote for the right-wing party in that communa, $\rho_{I, t}$ is a provincial level fixed effect at each time period which represents the propensity to vote for the right-wing party in province $I$ at time $t$, and $\tau_{t}^{h}$ represents the specific propensity for a voter of type $h$ to vote for the right-wing party at time $t$. The error component, $\varepsilon_{i, t}$, satisfies the usual conditions. Rearranging equation (5.1) above, and using the fact that $V_{i, t}=V_{i, t}^{i n q}+V_{i, t}^{a g r}+V_{i, t}^{n a}$, we obtain:

$$
R V_{i, t}=\left(\rho_{I, t}+\tau_{t}^{n a}\right) V_{i, t}+\left(\tau_{t}^{i n q}-\tau_{t}^{n a}\right) V_{i, t}^{i n q}+\left(\tau_{t}^{a g r}-\tau_{t}^{n a}\right) V_{i, t}^{a g r}+\left(\theta_{i}+\varepsilon_{i, t}\right) V_{i, t} .
$$

Dividing both sides of the equation by $V_{i, t}$, one gets:

$$
\frac{R V_{i, t}}{V_{i, t}}=\rho_{I, t}+\tau_{t}^{n a}+\left(\tau_{t}^{i n q}-\tau_{t}^{n a}\right) \frac{V_{i, t}^{i n q}}{V_{i, t}}+\left(\tau_{t}^{a g r}-\tau_{t}^{n a}\right) \frac{V_{i, t}^{a g r}}{V_{i, t}}+\theta_{i}+\varepsilon_{i, t},
$$

that potentially can be directly estimated. However, we have no information on the number of voters per category of occupation, $V_{i, t}^{h}$. Moreover, even between 1957 and 1965, the number of registered voters in the population varied.

To address these issues we have to make assumptions in order to determine the proportion of voters per occupational category, and we will investigate different alternatives. In Model 1, we assume that the change in registration is homogenous across all social classes in a given communa, but may differ across communas: $\frac{V_{i, t}}{V_{i, t_{0}}}$ is specific to communa $i$. Moreover, we also assume that, at time $t_{0}$, the probability that an inquilino is registered as an elector is the same across all communas. ${ }^{23}$ Letting $N_{i, t}^{i n q}$ represent the number of inquilinos in communa $i$ at time $t$, we can then write:

$$
\frac{V_{i, t}^{i n q}}{N_{i, t}^{i n q}}=\frac{V_{i, t}}{V_{i, t_{0}}} \frac{V_{t_{0}}^{i n q}}{N_{t_{0}}^{i n q}} \Leftrightarrow \frac{V_{i, t}^{i n q}}{V_{i, t}}=\frac{V_{t_{0}}^{i n q}}{N_{t_{0}}^{i n q}} \frac{N_{i, t}^{i n q}}{V_{i, t_{0}}} .
$$

\footnotetext{
${ }^{23}$ As we shall see, this assumption is necessary to identify the impact of the prevalence of inquilinos in the electorate. If the proportion of inquilinos voting in 1957 is arbitrary, identification becomes impossible, as the impact of the electoral reform on the 1965 electoral results can always be explained by differences in the registration of inquilinos in 1957 between communas.
} 
where $\frac{V_{t_{0}}^{i n q}}{N_{t_{0}}^{i n q}}$ is not specific to communa $i$, and $\frac{V_{i, t}}{V_{i, t_{0}}}$, the change in registration rate in communa $i$, is not specific to an occupational category.

We make a similar assumption for the other agricultural workers (though our main tests do not require this), where $N_{i, t}^{a g r}$ represents the number of agricultural workers other than inquilinos in communa $i$ at time $t$ :

$$
\frac{V_{i, t}^{a g r}}{V_{i, t}}=\frac{V_{t_{0}}^{a g r}}{N_{t_{0}}^{a g r}} \frac{N_{i, t}^{a g r}}{V_{i, t_{0}}} .
$$

Using these two expressions in equation (5.2), and rearranging those terms, we obtain:

$$
\frac{R V_{i, t}}{V_{i, t}}=\rho_{I, t}+\tau_{t}^{n a}+\left(\left(\tau_{t}^{i n q}-\tau_{t}^{n a}\right) \frac{V_{t_{0}}^{i n q}}{N_{t_{0}}^{i n q}}\right) \frac{N_{i, t}^{i n q}}{V_{i, t_{0}}}+\left(\left(\tau_{t}^{a g r}-\tau_{t}^{n a}\right) \frac{V_{t_{0}}^{a g r}}{N_{t_{0}}^{a g r}}\right) \frac{N_{i, t}^{a g r}}{V_{i, t_{0}}}+\theta_{i}+\varepsilon_{i, t},
$$

which represents the basic equation to be estimated. For further interpretation, it is convenient to rewrite the latter by considering only two time periods, 1957 and 1965, as well as by introducing explicitly provincial dummies, $D_{I}$, (which is equal to 1 if communa $i$ belongs to province $I$ and zero otherwise) and a time dummy $t_{65}$ corresponding to year 1965 . We then have:

$$
\begin{aligned}
\frac{R V_{i, t}}{V_{i, t}}= & \theta_{i}+\sum_{I} \rho_{I, 57} D_{I}+\tau_{57}^{n a}+\sum_{I} \rho_{I, \Delta 65} D_{I} t_{65}+\tau_{\Delta 65}^{n a} t_{65} \\
& +\beta_{57} \frac{N_{i, t}^{i n q}}{V_{i, 57}}+\beta_{\Delta 65} \frac{N_{i, t}^{i n q}}{V_{i, 57}} t_{65}+\gamma_{57} \frac{N_{i, t}^{a g r}}{V_{i, 57}}+\gamma_{\Delta 65} \frac{N_{i, t}^{a g r}}{V_{i, 57}} t_{65}+\varepsilon_{i, t},
\end{aligned}
$$

where $\theta_{i}+\sum_{I} \rho_{I, 55} D_{I}+\tau_{57}^{n a}$, represents the (total) communa level fixed effect. The basic test we want to carry out is the following. Before the secret ballot was introduced, $\beta_{57}>0$ and $\beta_{57}>\gamma_{57}$ so that the right-wing party gets more votes in a communa with more inquilinos compared to other voters, and particularly other agricultural workers. The main impact of the electoral reform is that, after 1958 , inquilinos can vote freely. We therefore expect $\beta_{\Delta 65}<0$, as the influence of inquilinos on the electoral results of the right-wing party should fall significantly after 1958. We also expect that inquilinos in 1965 will vote like the other agricultural workers, so that $\beta_{57}+\beta_{\Delta 65}=\gamma_{57}+\gamma_{\Delta 65}$ (or $=0$ if we assume that the 
other agricultural workers do not vote differently than the non-agricultural social classes). This last expression represents our main empirical test.

As said above, the number of registered voters increased during those years. In Model 1, we assume that, within a commune, the increase in registration is identical across all social classes. However, if non-inquilinos are more likely to be registered in 1965 than in 1957, this can then potentially introduce a bias in our estimates if the registration of non-inquilinos is negatively correlated with the proportion of inquilinos in the voting population at time $t_{0}$. In this case the 1965 effect we are capturing may simply be the effect of an increase in registration that is biased against inquilinos. This is a difficult issue, to which we cannot provide a simple answer. (Note however that what this argument points out is that the effect of the electoral reforms on the 1965 elections may be over-estimated. But it leaves unbiased the coefficients associated with the inquilinos before the reform.)

Model 2 assumes that, across all communas and across time, the proportion of voting inquilinos in the inquilino population remains constant:

$$
\frac{V_{i, t}^{i n q}}{N_{i, t}^{i n q}}=\frac{V_{t_{0}}^{i n q}}{N_{t_{0}}^{i n q}} \Leftrightarrow \frac{V_{i, t}^{i n q}}{V_{i, t}}=\frac{V_{t_{0}}^{i n q}}{N_{t_{0}}^{i n q}} \frac{N_{i, t}^{i n q}}{V_{i, t}}
$$

This assumption implies that any increase in the proportion of registered voters takes place among non-inquilinos (an extreme version of the above argument). Under this assumption, it seems more reasonable to neglect the potential difference in voting behavior between the two other classes, the explicit incorporation of which requires additional assumptions to determine which classes benefitted most from the increase in registration. (In effect, we therefore assume that the other agricultural workers do not vote differently from the other non-agricultural classes.) Note that we still assume that, at time $t_{0}$, the probability that an inquilino is registered as an elector, $\left(\frac{V_{t_{0}}^{i n q}}{N_{t_{0}}^{i n q}}\right)$, is not communa-specific. Rewriting equation (5.3) under these assumptions, we obtain:

$$
\frac{R V_{i, t}}{V_{i, t}}=\rho_{I, t}+\tau_{t}^{n i n q}+\left(\left(\tau_{t}^{i n q}-\tau_{t}^{n i n q}\right) \frac{V_{t_{0}}^{i n q}}{N_{t_{0}}^{i n q}}\right) \frac{N_{i, t}^{i n q}}{V_{i, t}}+\theta_{i}+\varepsilon_{i, t},
$$


or, following eq(5.4):

$$
\begin{aligned}
\frac{R V_{i, t}}{V_{i, t}}= & \theta_{i}+\sum_{I} \rho_{I, 57} D_{I}+\tau_{57}^{n i n q}+\sum_{I} \rho_{I, \Delta 65} D_{I} t_{65}+\tau_{\Delta 65}^{n i n q} t_{65} \\
& +\beta_{57} \frac{N_{i, t}^{i n q}}{V_{i, t}}+\beta_{\Delta 65} \frac{N_{i, t}^{i n q}}{V_{i, t}} t_{65}+\varepsilon_{i, t} .
\end{aligned}
$$

The equation above can also be directly estimated, since the RHS variable is simply the number of inquilinos at time $t$ divided by the number of voters at time $t$ (instead of at time $t_{0}$ as in model (1)). Again, the strategy consists in testing $\beta_{57}>0, \beta_{\Delta 65}<0$, and $\beta_{57}+\beta_{\Delta 65}=0$.

In Model 3, we assume that the number of voting inquilinos remains constant throughout the period, while keeping the assumption that, at time $t_{0}$, the probability that an inquilino is registered as an elector is not communa-specific. We have:

$$
\frac{V_{i, t}^{i n q}}{V_{i, t}}=\frac{V_{i, t_{0}}^{i n q}}{V_{i, t}}=\frac{V_{t_{0}}^{i n q}}{N_{t_{0}}^{i n q}} \frac{N_{i, t_{0}}^{i n q}}{V_{i, t}} .
$$

This implies that any increase in the number of registered voters took place among non-inquilinos. Once again neglecting potential voting differences between the other agricultural workers and the non-agricultural classes, equation (5.3) becomes:

$$
\frac{R V_{i, t}}{V_{i, t}}=\rho_{I, t}+\tau_{t}^{n i n q}+\left(\left(\tau_{t}^{i n q}-\tau_{t}^{n i n q}\right) \frac{V_{t_{0}}^{i n q}}{N_{t_{0}}^{i n q}}\right) \frac{N_{i, t_{0}}^{i n q}}{V_{i, t}}+\theta_{i}+\varepsilon_{i, t},
$$

which we rewrite:

$$
\begin{aligned}
\frac{R V_{i, t}}{V_{i, t}}= & \theta_{i}+\sum_{I} \rho_{I, 57} D_{I}+\tau_{57}^{n i n q}+\sum_{I} \rho_{I, \Delta 65} D_{I} t_{65}+\tau_{\Delta 65}^{n i n q} t_{65} \\
& +\beta_{57} \frac{N_{i, 57}^{i n q}}{V_{i, t}}+\beta_{\Delta 65} \frac{N_{i, 57}^{i n q}}{V_{i, t}} t_{65}+\varepsilon_{i, t} .
\end{aligned}
$$

Equation (5.8) can also be directly estimated, using the number of inquilinos in communa $i$ in 1957 divided by the total number of voters in that communa at time $t$. An extreme version of this model requires that, in 1957, all inquilinos were 
registered, thereby implicitly assuming that $\frac{V_{t_{0}}^{i n q}}{N_{t_{0}}^{i n q}}=1$ in equation (5.7) above, but leads to the same specification as in equation (5.8).

In Model 4, we assume that the probability that an agent votes in municipality $i$ is identical across all classes, and equal to the share of agents of that class in the population of the municipality (proportional registration). Registration rates are communa specific, however. We then have:

$$
\frac{V_{i, t}^{i n q}}{V_{i, t}}=\frac{N_{i, t}^{i n q}}{N_{i, t}}, \frac{V_{i, t}^{a g r}}{V_{i, t}}=\frac{N_{i, t}^{a g r}}{N_{i, t}},
$$

where $N_{i, t}$ represents the total population in that communa at time $t$. Combining the latter expressions with equation (5.3), one gets:

$$
\frac{R V_{i, t}}{V_{i, t}}=\rho_{I, t}+\tau_{t}^{n a}+\left(\tau_{t}^{i n q}-\tau_{t}^{n a}\right) \frac{N_{i, t}^{i n q}}{N_{i, t}}+\left(\tau_{t}^{a g r}-\tau_{t}^{n a}\right) \frac{N_{i, t}^{a g r}}{N_{i, t}}+\theta_{i}+\varepsilon_{i, t},
$$

or; more explicitly:

$$
\begin{aligned}
\frac{R V_{i, t}}{V_{i, t}}= & \theta_{i}+\sum_{I} \rho_{I, 57} D_{I}+\tau_{57}^{n a}+\sum_{I} \rho_{I, \Delta 65} D_{I} t_{65}+\tau_{\Delta 65}^{n a} t_{65} \\
& +\beta_{57} \frac{N_{i, t}^{i n q}}{N_{i, t}}+\beta_{\Delta 65} \frac{N_{i, t}^{i n q}}{N_{i, t}} t_{65}+\gamma_{57} \frac{N_{i, t}^{a g r}}{N_{i, t}}+\gamma_{\Delta 65} \frac{N_{i, t}^{a g r}}{N_{i, t}} t_{65}+\varepsilon_{i, t} .
\end{aligned}
$$

This equation requires to use the proportion of inquilinos in the population of the municipality at time $t$ as the measure of voting inquilinos. Note here that assuming proportional registration for the other agricultural workers allows us to introduce them separately in our estimation, as in equation (5.4).

Model 5 requires that the proportion of voting members of a particular class in the voting population is constant across time. As in Models 1, 2 and 3, we still assume that the probability that a member of a particular class is a voter at time $t_{0}$ is not specific to a particular municipality. We have:

$$
\frac{V_{i, t}^{i n q}}{V_{i, t}}=\frac{V_{i, t_{0}}^{i n q}}{V_{i, t_{0}}}=\frac{V_{t_{0}}^{i n q}}{N_{t_{0}}^{i n q}} \frac{N_{i, t_{0}}^{i n q}}{V_{i, t_{0}}}, \frac{V_{i, t}^{a g r}}{V_{i, t}}=\frac{V_{i, t_{0}}^{a g r}}{V_{i, t_{0}}}=\frac{V_{t_{0}}^{a g r}}{N_{t_{0}}^{a g r}} \frac{N_{i, t_{0}}^{a g r}}{V_{i, t_{0}}} .
$$


Note that this assumption still allows inquilinos to be over-represented in 1957.

A variant of Model 4 is to assume that, in 1957, inquilinos are over-represented as voters to the point that all inquilinos are registered as voters, while, after the 1958 reform, the probability of voting is identical across classes. To simplify, we also ignore differences in voting behavior among the remaining social classes. We then have:

$$
\frac{V_{i, t}^{i n q}}{V_{i, t}}=\frac{N_{57}^{i n q}}{V_{i, 57}} \text { in } 1957 \text { and } \frac{V_{i, t}^{i n q}}{V_{i, t}}=\frac{N_{i, t}^{i n q}}{N_{i, t}} \text { in 1961, } 1965 .
$$

This specification will be referred to as Model 6 in the estimations below.

It is clear that not all models are equally defensible. Model 6 allows for the possibility of biased registration by landlords, whereby inquilinos are over-represented in the voting population in 1957. This is also a feature of Models 1, 2, 3 and 5. However, these last three models assume some stability for the subsequent elections: Model 1 assumes that the proportion of voting inquilinos increased at the same rate as for the other social classes, Model 2, that the proportion of voting inquilinos in the inquilino population remained constant, Model 3, that the number of voting inquilinos remained constant, and model 5 that the proportion of voting inquilinos in the voting population remained constant. By contrast, Model 6 implies that a large number of inquilinos lost their registration as voters, which runs against the facts. Indeed, even in 1965, voters represented only $25 \%$ of the total population: this actually implies that, between 1957 and 1965, the number of inquilinos increased four times or that more than 3/4 of the inquilinos were de-registered ! (The number of inquilinos actually declined by $8 \%$ over the period.) Similarly, the assumption in Model 3 that the number of voting inquilinos remained constant is also not very satisfactory. Model 4 does not allow for biased registration in favour of inquilinos before 1958. And Model 5 goes against the idea that increased registration after 1958 mostly favored the other social classes. As a result, the most relevant models are Models 1 and 2. As Model 1 allow us to explicitly incorporate the other agricultural workers without any additional assumptions, we will refer to it as our basic model. The other models will be used mainly to show that our main results are not too sensitive to the particular assumptions made on the registration process of inquilinos. 


\subsubsection{The basic results}

The information we have on inquilinos, total population, and the agricultural labour force in a municipality comes from the two agricultural censuses of 1955 and 1965. For the elections of 1965, we used the information from the 1965 census, while for the elections of 1957 , we computed the corresponding figures, using linear interpolation between 1955 and 1965 .

The results of the panel estimations, with a communa fixed effect, are given in Table 3 below. Column (1) of Model 1 corresponds to equation (5.4) above, without the province*year dummies. By doing so, we impose homogeneity on the evolution of the votes across provinces (electoral results vary in the same way in all provinces and are therefore picked by the year dummy), thereby assuming that: $\rho_{I, \Delta 61}=\rho_{I, \Delta 65}=0, \forall I$.

In column (2), we allow provincial effects to vary with time, as a robustness check, as well as to reflect possibly changing state policies that could affect provinces differently (for instance, between cattle-raising and grain-growing areas). The inclusion of time-varying province effects may however affect the significance of our estimates, because of the provincial pattern in the prevalence of the inquilino system (i.e. multicollinearity). ${ }^{24}$ In column (2), we also include the following additional controls: total population and the proportion of land under large farms in the municipality. Column (3) presents the same specification as in column (1), but uses pooled OLS with a province fixed effect.

The results obtained using Model 2 is given in columns (4) and (5), with similar specifications as in columns (1) and (2). The corresponding estimates under Models 3, 4, 5 and 6 are given in columns (6)-(14).

\section{INSERT TABLE 3 HERE}

The results are striking, as they tend to confirm all the hypotheses made above. First, communas with more inquilinos are more likely to display stronger support in favour of the right-wing party in 1957. Thus, following column (1), in 1957, in a communa where the share of inquilinos in the number of voters is greater by

\footnotetext{
${ }^{24}$ As can be expected, the estimation results tend to be stronger in the absence of communa fixed effects (using pooled OLS) or in the absence of province*time dummies.
} 
one standard deviation (0.14), the expected share of the right-wing party is higher by $6.1 \%$. This represents a $15 \%$ increase in the average proportion of right-wing votes. It is worth noting that the coefficient attached to inquilinos in 1957 differs significantly from that attached to the other agricultural workers, which implies completely distinct voting behaviors between the two classes (and in many cases, $\beta_{57}>0$ and $\left.\gamma_{57}<0\right)$.

Moreover, the political influence of inquilinos disappears in 1965. The coefficient estimated, $\beta_{\Delta 65}$, is negative and significant, but $\beta_{57}+\beta_{\Delta 65}$ does not differ from $\gamma_{57}+\gamma_{\Delta 65}$, the corresponding coefficients for the other agricultural workers, nor from 0 which corresponds to the voting behavior of the non-agricultural classes. The imposition of secret ballot therefore had an important and significant effect, as the impact of inquilinos on right-wing votes completely vanishes in the 1965 elections. ${ }^{25}$

The results are consistent over the alternative specifications. The main coefficients of interest always have the anticipated sign, but sometimes lose significance. In particular, the results are weaker when we control for the interaction of province and time effects. This is a very demanding requirement however since in such a model we are only using the intra-province variation to identify the causal effect and this specification also introduces a problem of multicollinearity with the variables of interest. Models 3 and 6 also produce less satisfactory results, however these are the two models based on the least plausible identification assumptions.

To further test the robustness of the above results, we ran similar regressions using other indicators of the strength of patron-client relationships and of political control by a traditional landed oligarchy. Instead of using the proportion of voters of different types in the voting population, we used the proportion of inquilinos in the agricultural labour force in 1957 and 1965 as a measure of the intensity of the patron-client relationships in the communa, and a measure of land concentration, the share of area owned by farms larger than 200 hectares in the total agricultural

\footnotetext{
${ }^{25}$ Although not reported here, the provincial dummies attached to the 'oligarchic' provinces of O'Higgins, Aconcagua and Colchagua are always significant for the 1965 elections (equal to $-0.16,-0.19$ and -0.26 respectively, all significant at the $1 \%$ level). (While we cannot estimate the provincial fixed effect for 1957 with the panel regressions, the corresponding estimates obtained with the pooled OLS for 1957 are $0.15,0.27$ and 0.33 , all significant at the $1 \%$ level).
} 
area of the communa. ${ }^{26}$ We report the results of these estimations in table 4 below. The estimates, though less precise than in the basic model, are once again entirely consistent with our main hypotheses. It must be noted, however, that many coefficients associated with land concentration or agrarian relations in 1965 loose their significance when interacted time and provincial dummies are included in the model, though they remain consistently negative. This once again may be partly attributed to the multicollinearity with the interacted time and provincial dummies, as well as to the less precise nature of the indicators used. Interestingly, when we run a regression using both the proportion of inquilinos and the measure of land concentration as in column (17), the latter looses all significance, contrary to the former. This suggests that land concentration had less implications for the political outcome of a municipality than the intensity of the patron-client relationship, which is perfectly consistent with our model. ${ }^{27}$

The last three columns of table 4 present the results obtained when one uses the proportion of inquilinos in the population of a municipality in 1935. One can argue that this variable is a good measure of the importance of inquilinos, as it predates the elections under study, and is therefore less susceptible of a possible endogeneity bias. The results fully support our assumptions. Note that, with a panel fixed effect, we cannot estimate the coefficients attached to variables which remain constant over time, in particular the one related to the 1957 elections. They are estimated using pooled OLS in column (20).

\section{INSERT TABLE 4 HERE}

The above estimates excluded the 1961 elections. The problem comes from the fact that the number of inquilinos are observed only in two years, 1955 and 1965, so that our main estimations cover the two closest election dates, 1957 and 1965. We now use the 1961 electoral results, where the number of inquilinos

\footnotetext{
${ }^{26}$ Again the 1957 figures were obtained by linear interpolation between 1955 and 1965 . These land concentration measures are imprecise however, as the censuses only report at the communa level the number of farms per size category. By taking the median of each size class, we computed an estimate of the areas, that we used to compute the shares in area.

${ }^{27}$ Note that large farms were also found in cattle-raising areas in the North and in the South of Chile, where few inquilinos were found. The correlation between land concentration and the proportion of inquilinos in the agricultural labour force is only 0.22 .
} 
and the other relevant variables for 1961 were obtained by linear interpolation between 1955 and 1965. In table 5, we present the results obtained under the five different models discussed above. Note that, since the 1961 elections were close to the electoral reform and all political adjustments might not be instantaneous, we expect $0>\beta_{\Delta 61} \geq \beta_{\Delta 65}$ : we expect the impact of the electoral reform to develop more fully in 1965 than in 1961. The results are presented in Table 5 below.

\section{INSERT TABLE 5 HERE}

The results follow closely our former results. The coefficients, and their standard errors, associated with the 1957 and 1965 elections are almost identical. For the 1961 elections, the results are less conclusive, as the coefficient $\beta_{\Delta 61}$ associated with the inquilinos in 1961 is almost everywhere negative, but not systematically significant. As expected, the coefficients associated with the 1961 election are smaller (in absolute value) than the corresponding ones in 1965. The last column presents the results obtained when using the proportion of inquilinos in the population in 1935, with significant and negative coefficients for the 1961 and 1965 elections.

\subsubsection{Christian Democratic votes}

We ran similar regressions using the vote share of the Christian Democratic party as the dependent variable. One can argue that, after the introduction of the secret ballot, inquilinos are more likely to vote for that party than for any other party. (We also ran similar regressions on the socialist and the Christian Democratic parties together, with very similar results.) The focus on the Christian Democratic party follows from the fact that, historically, peasant and female voters constituted their political base, while the socialist party drew more support from men and blue collar workers.

The estimates are given in table 6 below, where we followed the specification used in the six models above. The results are once again supportive of our hypothesis. While, before 1958, the communas with a higher proportion of inquilinos tend to vote less in favour of the left-wing parties, this impact completely disappears in 1965. The estimates are consistent across the various specifications, though 
not always significant, particularly when time* province dummies and additional controls, such as land concentration or population are used.

INSERT TABLE 6 HERE

\section{Conclusions}

In this paper we have investigated how the employment relationship, if it generates rents, may allow employers to control the political behavior of their workers. The salient example of this is voting behavior when there is no secret ballot, so that political behavior is observable. Interestingly, the rents conceded by employers to workers gives the former a comparative advantage in controlling the political activities of the latter, relative to political parties. We showed that this helps to explain one of the big stylized facts about polities with endemic electoral corruption, namely that employers supply votes to parties rather than the parties buying most votes separately from individuals. The ability to sell votes increases the demand for labor and generates an added incentive to own land, driving up its price.

We test the predictions of the model by examining in detail the effects of the introduction of the secret ballot in Chile in 1958. We show that, consistent with our theory, the political reforms led to large changes in voting behavior. Before the reforms, localities with more pervasive patron-client relationships tend to exhibit a much stronger support for the right-wing parties, traditionally associated with the landed oligarchy. After the reform however, this difference across localities completely disappeared. This evidence suggests to us that electoral corruption, and the economic and political incentives that it created, is an important part of the story for why inequality has been so high historically in Latin America and possibly also an important part of the story about why long-run economic performance in Latin American has been so disappointing (on which see Engerman and Sokoloff, 2005, and Posada-Carbó, 2000, who argue for the central importance of electoral corruption in Latin American political history). Though our analysis focused on vote buying, this can be thought of as a metaphor for a wide variety of political favors or policies that transfer rents to the landlords. Moreover, the 
political control that rents allow employers to exercise applies much more generally, even in situations where there is an effective secret ballot. Any type of observable political activity, collective actions, demonstrations, trade unionism, political activism, can all be controlled by the threat of losing ones employment and the rent that it provides. 


\section{References}

Acemoglu, Daron and James A. Robinson (2006) Economic Origins of Dictatorship and Democracy, New York; Cambridge University Press.

Anderson, Margaret L. (1993) "Voter, Junker, Landrat, Priest: The Old Authorities and the New Franchise in Imperial Germany," American Historical Review, 98, 1448-1474.

Austen-Smith, David (2000) "Income Redistribution under Proportional Representation," Journal of Political Economy, 108, 1235-1269.

Banerjee, Abhijit V., Paul J. Gertler and Maitreesh Ghatak (2002) "Empowerment and Efficiency: Analysis of a Tenancy Reform in West Bengal," Journal of Political Economy, 110, 239-280.

Banerjee, Abhijit V. and Andrew F. Newman (1993) "Occupational Choice and the Process of Development," Journal of Political Economy, 101, 274298.

Baron, David P. and Daniel Diermeier (2001) "Elections, Governments, and Parliaments in Proportional Representation Systems," Quarterly Journal of Economics, 933-967.

Bauer, Arnold J. (1975) Chilean Rural Society from the Spanish Conquest to 1930, Cambridge University Press, Cambridge UK.

Bauer, Arnold J. (1995) "Landlord and Campesino in the Chilean Road to Democracy," in Evelyn Huber and Frank Safford eds. Agrarian Structure and Political Power: Landlord and Peasant in the Making of Latin America, University of Pittsburgh Press, Pittsburgh, PA.

Bendix, Reinhard (1964) Nation-Building and Citizenship, John Wiley and Sons, New York.

Blackbourn, David (1998) The Long Nineteenth Century: A History of Germany, 1780-1918, Oxford University Press, New York NY.

Breman, Jan (1974) Patronage and Exploitation: Changing Agrarian Relations in South Gujarat, India, University of California Press, Berkeley CA.

Buchanan, James and Gordon Tullock (1962) The Calculus of Consent, Ann Arbor; University of Michigan Press. 
Castro, José Luis (1941) El Sistema Electoral Chileno, Nascimento, Santiago.

Collier, Ruth Berins and David Collier (1991) Shaping the Political Arena, Princeton University Press, Princeton NJ.

Cox, Gary W. (1987) The Efficient Secret: The Cabinet and the Development of Political Parties in Victorian England, Cambridge University Press, New York NY.

Cox, Gary W. (1997) Making Votes Count, Cambridge University Press, New York, NY.

Cruz-Coke, Ricardo (1984) Historia Electoral de Chile, 1925-1973, Editorial Juridicia de Chile, Santiago.

Dekel, Eddie, Matthew O. Jackson and Asher Wolinsky (2004) "Vote Buying," Unublished California Institute of Technology.

Engerman Stanley L. and Kenneth L. Sokoloff (2005) "The Evolution of Suffrage Institutions in the New World," Journal of Economic History, 65, 891-921

Ffrench-Davies, Ricardo (1973) Políticas Económicas en Chile, 19521970, Ediciones Nueva Universidad, Santiago Chile.

Gash, Norman (1977) Politics in the Age of Peel, Harvester Press, Hassocks UK.

Gibson, Ralph and Martin Blinkhorn (1991) Landownership and Power in Modern Europe, Harper Collins, New York NY.

Gil, Frederico G. (1966) The Political System of Chile, Houghton Mifflin, Boston MA.

Goldstein, Richard J. (1983) Political Repression in Nineteenth Century Europe, Croon Helm, London UK.

Graham, Richard (1990) Patronage and Politics in Nineteenth Century Brazil, Stanford University Press, Stanford CA.

Grossman, Gene M. and Elhanan Helpman (1996) "Electoral Competition and Special Interest Politics," Review of Economic Studies, 63, 265-286.

Hamerow, Theodore S. (1974) The Social Foundations of German Unification, 1858-1871: Struggles and Accomplishments, Princeton University Press, 
Princeton NJ.

Hartlyn, Jonathan and Arturo Valenzuela (1998) "Democracy in Latin America since 1930," in Leslie Bethell ed. Latin America: Politics and Society since 1930, Cambridge University Press, Cambridge UK.

Hellinger, Daniel (1978) "Electoral Change in the Chilean Countryside: the Presidential Elections of 1958 and 1970", The Western Political Quarterly, 31(2), 253-73.

Kaufman, Robert E. (1972) The Politics of Land Reform in Chile, 19501970: Public Policy, Political Institutions, and Social Change, Harvard University Press, Cambridge MA.

Kinzer, Brian L. (1982) The Ballot Question in Nineteenth Century English Politics, Garland, New York NY.

Kitson-Clark, G.S.R. (1951) "The Electorate and the Repeal of the Corn Laws," Transactions of the Royal Historical Society, 1, 109-126.

Kohli, Atul (1990) Democracy and Discontent: India's Growing Crisis of Governability, Princeton University Press, Princeton NJ.

Kreuzer, Marcus (1996) "Democratization and Changing Methods of Electoral Corruption in France from 1815 to 1914," in Walter Little and Eduardo Posada-Carbó eds. Political Corruption in Europe and Latin America, MacMillan, London.

Legros, Patrick and Andrew F. Newman (1996) "Wealth Effects, Distribution, and the Theory of Organization," Journal of Economic Theory, 70, 312-341.

Loveman, Brian (1976) Struggle in the Countryside: Politics and Rural Labor in Chile, 1919-1973, University of Indiana Press, Bloomington IN.

Loveman, Brian (2001) Chile: The Legacy of Hispanic Capitalism, 3rd Edition, New York; Oxford University Press.

Malefakis, Edward E. (1970) Agrarian Reform and Peasant Revolution in Spain, Yale University Press, New Haven CT.

Marglin, Stephen A. (1974) "What do Bosses Do?" Review of Radical Political Economy, 6, 60-112.

Martins, José de Souza (1996) "Clientalism and Corruption in Contempo- 
rary Brazil," in Walter Little and Eduardo Posada-Carbó eds. Political Corruption in Europe and Latin America, MacMillan, London.

Millar Carvacho, René (1981) La Elección Presidencial de 1920: Tendencias y Prácticas Políticas en el Chile Parlamentario, Ediciones Universitaria, Santiago.

Mookherjee, Dilip (1997) "Informational Rents and Property Rights in Land," in John E. Roemer ed. Property Rights, Incentives and Welfare, MacMillan, London UK.

Morodo, Raúl (1968) Política y partidos en Chile. Las elecciones de 1965, Madrid: Taurus.

O'Gorman, Frank (1989) Voters, Patrons and Parties: The Unreformed Electoral System of Hanovarian England, 1734-1832, Clarendon Press, Oxford UK.

Pang, Eul-Soo. (1973) "Coronelismo in Northeastern Brazil," in Robert Kern ed. The Caciques: Oligarchical Politics and the System of Caciquismo in the Luso-Hispanic World, University of New Mexico Press, Albuquerque NM.

Persson, Torsten and Guido Tabellini (2000) Political Economics: Explaining Economic Policy, MIT Press, Cambridge, Mass.

Persson, Torsten and Guido Tabellini (2003) The Economic Effects of Constitutions, forthcoming MIT Press, Cambridge, Mass.

Petras, James and Maurice Zeitlin (1968) "Agrarian Radicalism in Chile," British Journal of Sociology, 19, 503-531.

Piketty, Thomas (1999) "The Information-Aggregation Approach to Political Institutions," European Economic Review, 43, 791-800.

Piketty, Thomas (2000) "Voting as Communicating," Review of Economic Studies, 67, 169-191.

Posada-Carbó, Eduardo (2000) "Electoral Juggling: A Comparative History of the Corruption of Suffrage in Latin America, 1830-1930," Journal of Latin American Studies, 32, 611-644.

Ricardo, David ([1824], 1951-1973) "Defense of the Plan of Voting by Ballot," in Maurice H. Dobb and Piero Sraffa eds. The Works and Correspondence of David Ricardo, Volume 5, Cambridge University Press, Cambridge UK. 
Sadoulet, Elisabeth (1992) "Labor-Service Tenancy Contracts in a Latin American Context," American Economic Review, 82, 1031-1042.

Scully, Timothy R. (1992) Rethinking the Center: Party Politics in Nineteenth and Twentieth Century Chile, Stanford University Press, Stanford CA.

Sinding, Steven W. (1972) "The Evolution of Chilean Voting Patterns: A Re-Examination of Some Old Assumptions," The Journal of Politics, 34, 774-796.

Snyder, James M. (1991) "On Buying Legislatures," Economics and Politics, 2, 93-110.

Summerhill, William (1995) "A Note on Some Economic Consequences of Electoral Reform in Imperial Brazil," Unpublished, Department of History UCLA.

Swift, Jeannine (1971) Agrarian Reform in Chile: An Economic Study, Heath Lexington Books, Lexington MA.

Valenzuela, Arturo (1978) The Breakdown of Democratic Regimes: Chile, Johns Hopkins University Press, Baltimore MD.

Valenzuela, J. Samuel (1985) Democratizion via Reforma: La Expansión del Sufragio en Chile, Ediciones del IDES, Buenos Aires, Argentina. 


\section{Appendix 1 Sources and methodology}

'Agricultural workers' and 'inquilinos' are the total number of agricultural workers and the total number of inquilinos working in the agricultural sector in 1935, 1955 and 1964-5 respectively. Source:II Censo Nacional Agricola Ganadero, 1935, Vol. 1-6, Servicio Nacional de Estadistica y Censos, Republica de Chile; III Censo Nacional Agricola Ganadero, 1955, Vol. 1-6, Servicio Nacional de Estadistica y Censos, Republica de Chile; IV Censo Nacional Agro-pecuario 1964-65, Vol. 1-26, Direccion de Estadistica y Censos, Republica de Chile. Population figures came from the 1940, 1952, 1960 and 1970 Censo de Poblacion, Centro Latinamericano de Demografia. 'Right-wing votes' is the proportion of votes in favor of the 'Conservador', 'Conservador Tradicionalista' and 'Liberal' parties in the total number of valid votes, in the parliamentary elections of 1957, 1961, and 1965 respectively; 'radical' refers to the proportion of votes in favor of the 'Radical' and 'Radical Doctrinario' parties in the total number of valid votes, in the parliamentary elections of 1957, 1961, and 1965 respectively; 'christian democrat' is the proportion of valid votes in favor of the 'Falangia Nacional', the 'Agrario Laboristas' and 'Partido Social Christiano Conservador' in 1957 and the 'Democrata Christiano' party for the years 1961, 1965 and 1969. The 'left' includes the proportion of valid votes in favor of the 'Communista', 'Socialista' and 'Socialista Popular' parties in 1957, 1961 and 1965 respectively. The regrouping of the political parties was made according to the methodology followed by Valenzuela (1978). The number of voters is the number of valid votes in the 1953 and 1957

elections. We chose parliamentary elections only because of their comparability across years and the stability of the major parties over the years. Presidential and Municipal elections in those years followed very closely the pattern followed by the parliamentary elections. Sources: Direccion del Registro Electoral, Election ordinaria de senadores y diputados al Congreso Nacional (periodo constitucional 1953-7), Chile; Direccion del Registro Electoral, Variacion Porcentual de los Partidos Politicos, 1957-1971, Chile. 


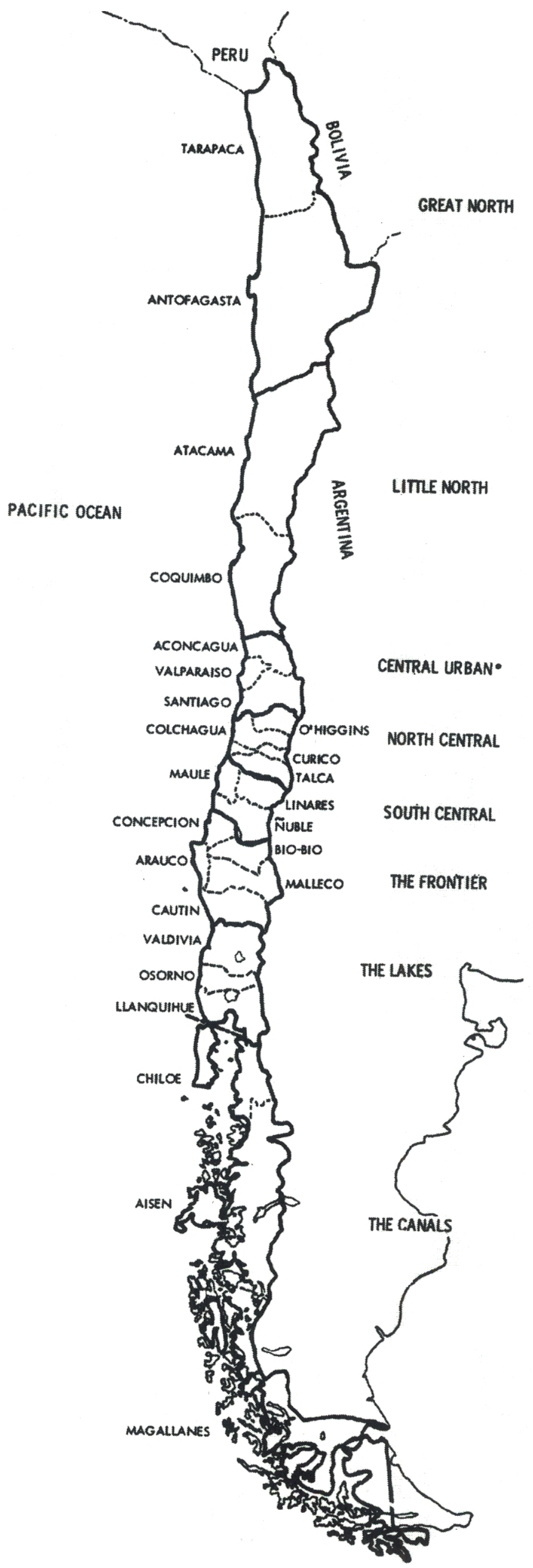


Figure 1: Right-wing votes in 1957 and 1965 and the ratio of inquilinos to registered voters in 1955 (scatter plot and simple regression line)
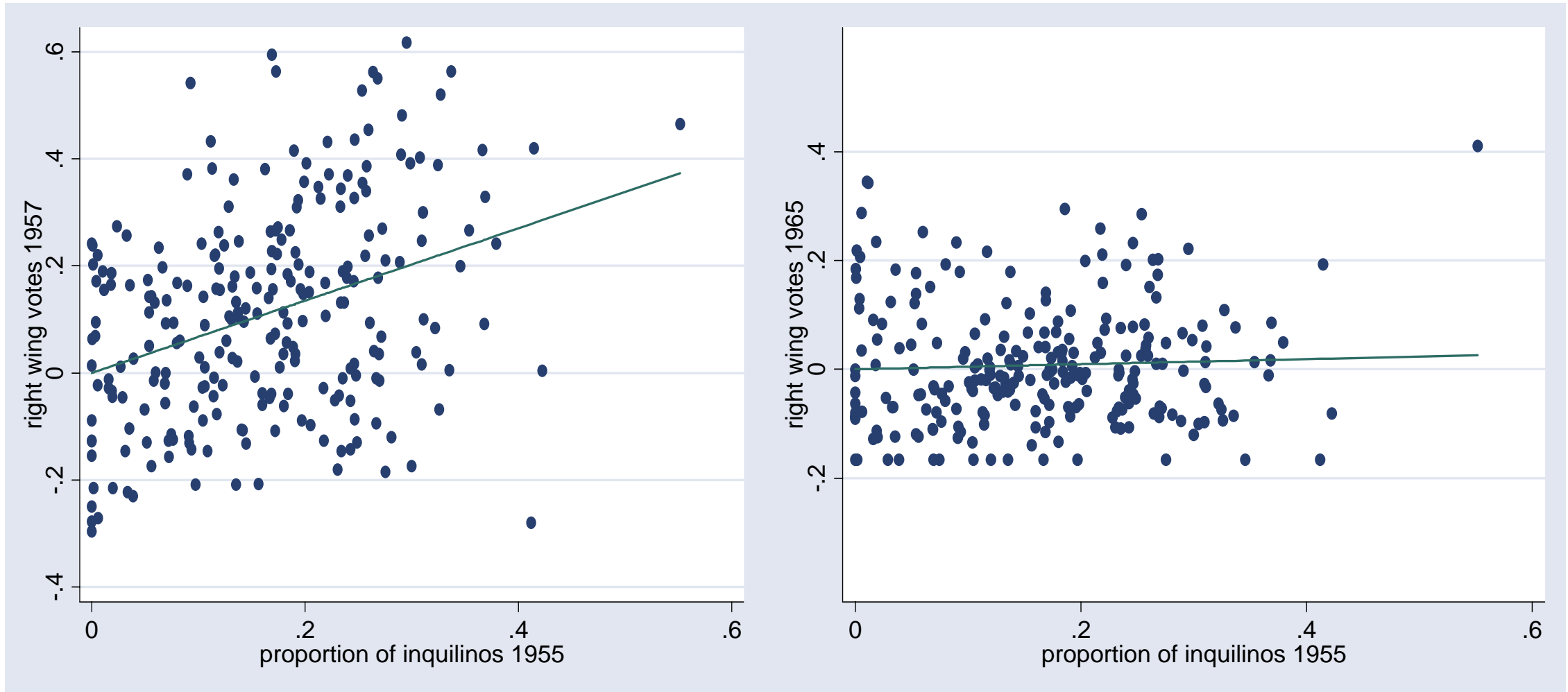

$$
\begin{aligned}
\text { Right57 }= & \begin{array}{l}
0.319+0.523 \text { Inq } / \text { voter55 } \\
(0.017)(0.078)
\end{array}
\end{aligned}
$$$$
\begin{aligned}
\text { Right65 }= & \begin{array}{l}
0.149+0.145 \text { Inq/voter55 } \\
(0.010)(0.047)
\end{array}
\end{aligned}
$$ 
Table 1: Agrarian relations, land concentration and electoral results in Chile

\begin{tabular}{|c|c|c|c|c|c|c|c|c|}
\hline Region & $\begin{array}{l}\text { Proportion } \\
\text { of } \\
\text { inquilinos } \\
\text { in the } \\
\text { population } \\
\text { in } 1935 \\
\\
\text { (\%) }\end{array}$ & $\begin{array}{l}\text { Proportion } \\
\text { of } \\
\text { inquilinos } \\
\text { in the } \\
\text { agricultural } \\
\text { labour } \\
\text { force in } \\
1955 \\
(\%)\end{array}$ & $\begin{array}{l}\text { Proportion } \\
\text { of } \\
\text { inquilinos } \\
\text { in the } \\
\text { number of } \\
\text { registered } \\
\text { voters } \\
\text { (1955-57) } \\
(\%)\end{array}$ & $\begin{array}{l}\text { Proportion } \\
\text { of right- } \\
\text { wing votes } \\
\text { in } 1957 \\
\text { elections } \\
\\
\text { (\%) }\end{array}$ & $\begin{array}{l}\text { Proportion } \\
\text { of right- } \\
\text { wing votes } \\
\text { in } 1965 \\
\text { elections } \\
\\
(\%)\end{array}$ & $\begin{array}{l}\text { Proportion } \\
\text { of } \\
\text { christian- } \\
\text { democratic } \\
\text { votes in the } \\
1957 \\
\text { elections } \\
\text { (\%) }\end{array}$ & $\begin{array}{l}\text { Proportion } \\
\text { of } \\
\text { christian- } \\
\text { democratic } \\
\text { votes in the } \\
1965 \\
\text { elections } \\
\text { (\%) }\end{array}$ & $\begin{array}{c}\text { Share of } \\
\text { total area } \\
\text { operated by } \\
\text { farms over } \\
200 \text { has in } \\
1955 \\
\\
(\%) \\
\end{array}$ \\
\hline $\begin{array}{l}\text { North Central Valley } \\
\text { (O’Higgins, Colchagua, } \\
\text { Curico, Talca) }\end{array}$ & 4.8 & 19.6 & 18.9 & 50.0 & 17.3 & 4.8 & 40.8 & 75.7 \\
\hline $\begin{array}{l}\text { Urban Central Valley } \\
\text { (Valparaiso, Santiago, } \\
\text { Aconcagua) }\end{array}$ & 3.8 & 19.1 & 17.2 & 40.8 & 16.0 & 8.6 & 47.1 & 88.5 \\
\hline $\begin{array}{l}\text { South Central Valley } \\
\text { (Maule, Linares, Nuble) }\end{array}$ & 4.5 & 12.7 & 14.6 & 40.5 & 17.2 & 4.9 & 39.0 & 60.1 \\
\hline $\begin{array}{l}\text { All Central Valley } \\
\text { Provinces }\end{array}$ & 4.3 & 17.4 & 17.1 & 44.4 & 16.9 & 6.0 & 42.1 & 74.9 \\
\hline $\begin{array}{l}\text { Frontier and Little North } \\
\text { Provinces (Concepcion, } \\
\text { Bio-bio, Arauco, Malleco, } \\
\text { Cautin, Atacama, } \\
\text { Coquimbo) }\end{array}$ & 3.2 & 10.8 & 11.2 & 31.2 & 11.8 & 7.4 & 33.7 & 68.9 \\
\hline $\begin{array}{l}\text { All other provinces } \\
\text { (Valdivia, Osorno, } \\
\text { Llanquihue, Chiloe, } \\
\text { Aysen, Magallanes, } \\
\text { Tarapaca, Antofagasta) } \\
\end{array}$ & 3.0 & 5.7 & 8.2 & 26.6 & 15.1 & 14.7 & 29.6 & 69.4 \\
\hline $\begin{array}{l}\text { Chile (average across all } \\
\text { provinces) }\end{array}$ & 3.8 & 11.8 & 12.6 & 35.0 & 14.8 & 8.7 & 35.8 & 71.4 \\
\hline
\end{tabular}

Note: For the Santiago province, we excluded the four exclusively urban districts of the city of Santiago. 
Table 2: Impact of agrarian relations on right-wing votes before and after the 1958 electoral reform

\begin{tabular}{|l|c|c|c|}
\hline & 1957 & 1965 & Difference 65-57 \\
\hline $\begin{array}{l}\text { Ratio of inquilinos to } \\
\text { the number of } \\
\text { registered voters in } \\
\begin{array}{l}1955 \text { below median } \\
(<0.134)\end{array}\end{array}$ & 0.321 & 0.159 & -0.162 \\
\hline $\begin{array}{l}\text { Ratio of inquilinos to } \\
\text { the number of } \\
\text { registered voters in } \\
1955 \text { above median }\end{array}$ & 0.491 & 0.188 & -0.303 \\
\hline Difference & 0.170 & 0.029 & $\mathbf{- 0 . 1 4 1}$ \\
\hline
\end{tabular}


Table 3: Impact of inquilinos on right-wing votes in 1957 and 1965

\begin{tabular}{|c|c|c|c|c|c|c|c|}
\hline & \multicolumn{3}{|c|}{ Model 1} & \multicolumn{2}{|c|}{ Model 2} & \multicolumn{2}{|c|}{ Model 3} \\
\hline & (1) & (2) & (3) & (4) & (5) & (6) & (7) \\
\hline Inquilino/voter & $\begin{array}{c}0.438^{* *} \\
(0.173)\end{array}$ & $\begin{array}{l}0.259^{*} \\
(0.153)\end{array}$ & $\begin{array}{c}0.451^{* * *} \\
(0.072)\end{array}$ & $\begin{array}{c}0.424 * * * \\
(0.144)\end{array}$ & $\begin{array}{c}0.318^{* *} \\
(0.129)\end{array}$ & $\begin{array}{c}0.760 * * * \\
(0.201)\end{array}$ & $\begin{array}{c}0.590 * * * \\
(0.184)\end{array}$ \\
\hline 1965*Inquilino/voter* & $\begin{array}{c}-0.435^{* * *} \\
(0.082)\end{array}$ & $\begin{array}{c}-0.294 * * * \\
(0.090)\end{array}$ & $\begin{array}{c}-0.278 * * * \\
(0.986)\end{array}$ & $\begin{array}{c}-0.369 * * \\
(0.144)\end{array}$ & $\begin{array}{l}-0.156 \\
(0.155)\end{array}$ & $\begin{array}{l}-0.093 \\
(0.172)\end{array}$ & $\begin{array}{l}-0.020 \\
(0.172)\end{array}$ \\
\hline $\begin{array}{l}\text { Other agricultural } \\
\text { workers/voter }\end{array}$ & $\begin{array}{c}-0.102 * * * \\
(0.031)\end{array}$ & $\begin{array}{l}-0.016 \\
(0.030)\end{array}$ & $\begin{array}{l}-0.006 \\
(0.010)\end{array}$ & - & - & - & - \\
\hline $\begin{array}{l}1965 * \text { Other agric. } \\
\text { workers/voter }\end{array}$ & $\begin{array}{c}0.047 * * * \\
(0.012)\end{array}$ & $\begin{array}{c}0.005 \\
(0.013)\end{array}$ & $\begin{array}{c}0.001 \\
(0.013)\end{array}$ & - & - & - & - \\
\hline Time dummy:1965 & $\begin{array}{c}-0.197^{* * *} \\
(0.019)\end{array}$ & $\begin{array}{c}-0.160 * * * \\
(0.047)\end{array}$ & $\begin{array}{c}-0.157 * * * \\
(0.056)\end{array}$ & $\begin{array}{c}-0.268^{* * *} \\
(0.016)\end{array}$ & $\begin{array}{c}-0.154 * * * \\
(0.046)\end{array}$ & $\begin{array}{c}-0.168 * * * \\
(0.016)\end{array}$ & $\begin{array}{c}-0.165^{* * *} \\
(0.045)\end{array}$ \\
\hline 1965*Province & - & Yes & Yes & - & Yes & - & Yes \\
\hline Other controls & - & Yes & Yes & - & Yes & - & Yes \\
\hline Communa fixed effect & Yes & Yes & No (pool. OLS) & Yes & Yes & Yes & Yes \\
\hline Provincial dummies & - & - & Yes & - & - & - & - \\
\hline \# obs. & 492 & 492 & 492 & 492 & 492 & 492 & 492 \\
\hline
\end{tabular}


Table 3 (ctd): Impact of inquilinos on right-wing votes in 1957 and 1965

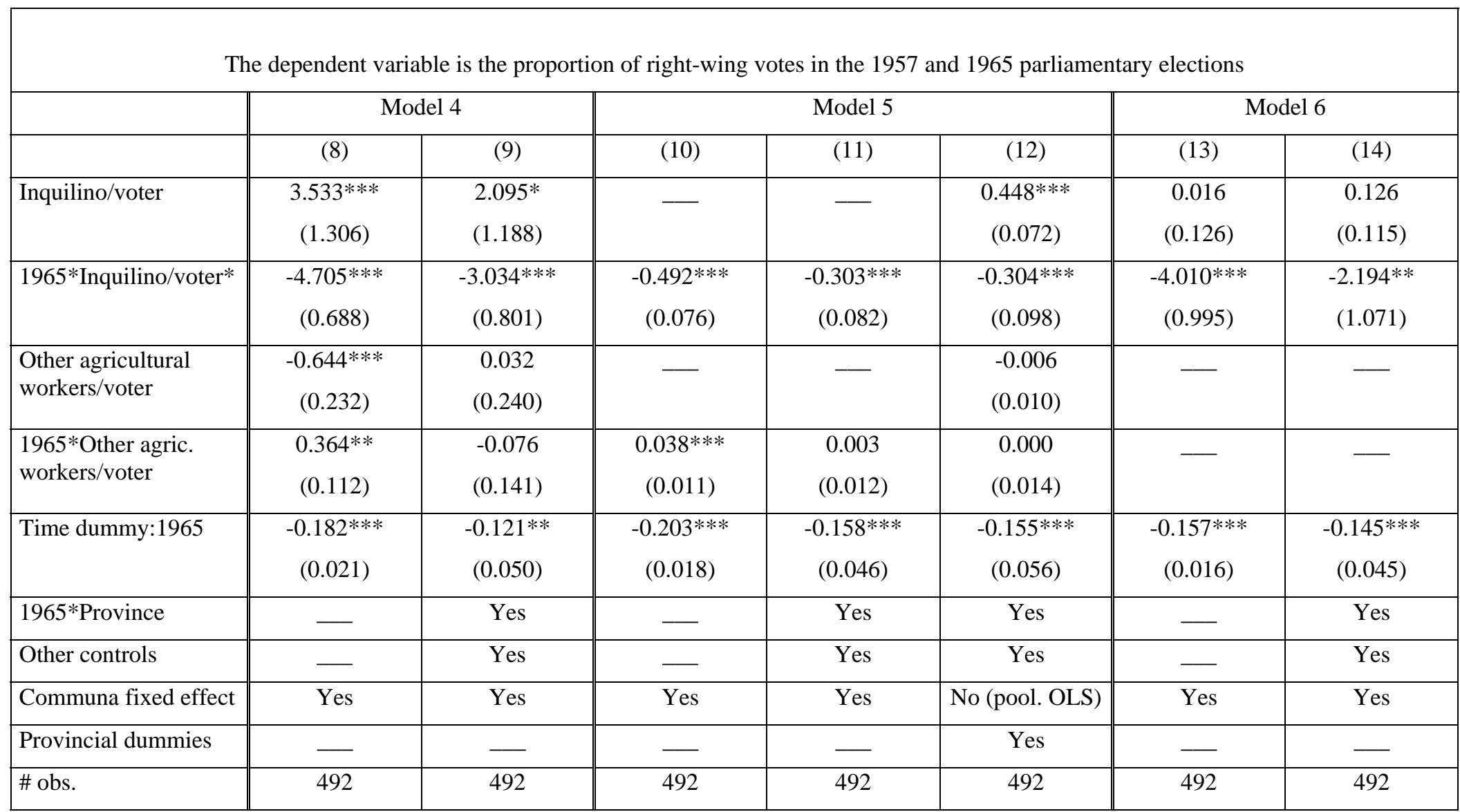

Note: Standard errors under brackets, ***indicates significance at the $1 \%$ level, ** at the $5 \%$ level and $*$ at the $10 \%$ level. The additional controls for equations (2), (3), (9), (11) and (12) are the proportion of land under large farms and the population in the municipality; for equations (5), (7) and (14), they also include the agricultural labour force. For the fixed effect estimates, the within R-square ranged between 0.69 and 0.84 , while the between R-square ranged between 0.02 and 0.26 . For equations (1) and (12), the adjusted $\mathrm{R}^{2}$ were 0.69 . 
Table 4: Impact of inquilinos on right-wing votes in 1957 and 1965: alternative measures and robustness checks

The dependent variable is the proportion of right-wing votes in the 1957 and 1965 parliamentary elections

\begin{tabular}{|c|c|c|c|c|c|c|c|c|}
\hline & $(15)$ & $(16)$ & $(17)$ & $(18)$ & $(19)$ & $(20)$ & $(21)$ & $(22)$ \\
\hline $\begin{array}{l}\text { Inquilinos/total agricultural } \\
\text { workers }\end{array}$ & $\begin{array}{c}1.063 * * * \\
(0.260)\end{array}$ & $\begin{array}{l}0.440 * \\
(0.249)\end{array}$ & - & - & $\begin{array}{l}0.461^{*} \\
(0.250)\end{array}$ & - & - & - \\
\hline $\begin{array}{l}1965 * \text { Inquilinos/total } \\
\text { agricultural workers }\end{array}$ & $\begin{array}{c}-1.023 * * * \\
(0.210) \\
\end{array}$ & $\begin{array}{l}-0.317 \\
(0.224) \\
\end{array}$ & - & - & $\begin{array}{r}-0.440 * \\
(0.259) \\
\end{array}$ & - & - & - \\
\hline $\begin{array}{l}\text { Proportion of land under large } \\
\text { farms }\end{array}$ & - & - & $\begin{array}{l}0.228 * \\
(0.120) \\
\end{array}$ & $\begin{array}{c}0.041 \\
(0.105)\end{array}$ & $\begin{array}{c}0.028 \\
(0.105) \\
\end{array}$ & - & - & - \\
\hline $\begin{array}{l}\text { 1965*Proportion of land under } \\
\text { large farms }\end{array}$ & - & - & $\begin{array}{c}-0.181 * * * \\
(0.051)\end{array}$ & $\begin{array}{c}0.004 \\
(0.051)\end{array}$ & $\begin{array}{c}0.056 \\
(0.059) \\
\end{array}$ & - & - & - \\
\hline Inquilinos/population in 1935 & - & - & - & - & - & $\begin{array}{c}1.502^{* * * *} \\
(0.384) \\
\end{array}$ & - & - \\
\hline $\begin{array}{l}1965 * \text { Inquilinos/population in } \\
1935\end{array}$ & - & - & - & - & - & $\begin{array}{c}-1.646 * * * \\
(0.507)\end{array}$ & $\begin{array}{c}-1.792^{* * *} \\
(0.459)\end{array}$ & $\begin{array}{c}-1.343^{* * *} \\
(0.445)\end{array}$ \\
\hline Time dummy:1965 & $\begin{array}{c}-0.112 * * * \\
(0.021) \\
\end{array}$ & $\begin{array}{c}-0.163 * * * \\
(0.049) \\
\end{array}$ & $\begin{array}{c}-0.097 * * \\
(0.039) \\
\end{array}$ & $\begin{array}{c}-0.211^{* * *} \\
(0.060) \\
\end{array}$ & $\begin{array}{r}-195 * * * \\
(0.060) \\
\end{array}$ & $\begin{array}{c}-0.177 * * * \\
(0.058) \\
\end{array}$ & $\begin{array}{c}-0.167 * * * \\
(0.021) \\
\end{array}$ & $\begin{array}{c}-0.163^{* * *} \\
(0.049) \\
\end{array}$ \\
\hline 1965*Province & - & Yes & - & Yes & Yes & Yes & - & Yes \\
\hline Other controls & - & Yes & - & Yes & Yes & Yes & - & Yes \\
\hline Provincial Dummies & - & - & - & - & - & Yes & - & - \\
\hline Communa fixed effect & Yes & Yes & Yes & Yes & Yes & $\begin{array}{l}\text { No (pooled } \\
\text { OLS) }\end{array}$ & Yes & Yes \\
\hline \# obs. & 492 & 492 & 492 & 492 & 492 & 422 & 422 & 422 \\
\hline
\end{tabular}

Notes: Standard errors under brackets, ***indicates significance at the $1 \%$ level, $* *$ at the $5 \%$ level and * at the $10 \%$ level. The additional controls for equations

(14), (18) and (19) were the agricultural labour force, the proportion of land under large farms and the population; for equations (16) and (17), the agricultural labour force and the population. For the fixed effect estimates, the within R-square ranged between 0.65 and 0.84 , while the between R-square ranged between 0.02 and 0.24 . For equation (18), the adjusted $\mathrm{R}^{2}$ was 0.70 . 
Table 5: Impact of inquilinos on right-wing votes in 1957, 1961 and 1965

The dependent variable is the proportion of right-wing votes in the 1957, 1961 and 1965 parliamentary elections (standard errors under brackets)

\begin{tabular}{|c|c|c|c|c|c|c|c|}
\hline & Model 1 & Model 2 & Model 3 & Model 4 & Model 5 & Model 6 & $\begin{array}{l}\text { Using } 1935 \\
\text { inquilino data }\end{array}$ \\
\hline & (23) & (24) & (25) & (26) & (27) & (28) & (29) \\
\hline Inquilino/voter & $\begin{array}{l}0.248^{*} \\
(0.137) \\
\end{array}$ & $\begin{array}{c}0.340^{* * *} \\
(0.107) \\
\end{array}$ & $\begin{array}{c}0.511^{* * *} \\
(0.150)\end{array}$ & $\begin{array}{l}1.920^{*} \\
(1.057)\end{array}$ & - & $\begin{array}{c}0.076 \\
(0.094) \\
\end{array}$ & - \\
\hline 1961*Inquilino/voter & $\begin{array}{c}-0.190^{* *} \\
(0.076)\end{array}$ & $\begin{array}{l}-0.025 \\
(0.084) \\
\end{array}$ & $\begin{array}{c}0.033 \\
(0.088) \\
\end{array}$ & $\begin{array}{c}-2.080^{* * *} \\
(0.688)\end{array}$ & $\begin{array}{c}-0.174^{* *} \\
(0.072)\end{array}$ & $\begin{array}{l}-0.918 \\
(0.877)\end{array}$ & - \\
\hline 1965*Inquilino/voter & $\begin{array}{c}-0.271^{* * *} \\
(0.080)\end{array}$ & $\begin{array}{l}-0.196 \\
(0.119)\end{array}$ & $\begin{array}{l}-0.074 \\
(0.147)\end{array}$ & $\begin{array}{c}-2.806^{* * *} \\
(0.703)\end{array}$ & $\begin{array}{c}-0.304 * * * \\
(0.074)\end{array}$ & $\begin{array}{c}-2.433 * * * \\
(0.895) \\
\end{array}$ & - \\
\hline $\begin{array}{l}\text { Other agricultural } \\
\text { workers/voter }\end{array}$ & $\begin{array}{l}-0.016 \\
(0.027) \\
\end{array}$ & - & - & $\begin{array}{c}0.090 \\
(0.203) \\
\end{array}$ & - & - & - \\
\hline $\begin{array}{l}1961 * \text { Other agricultural } \\
\text { workers/voter }\end{array}$ & $\begin{array}{c}0.017 \\
(0.010)\end{array}$ & - & - & $\begin{array}{c}0.115 \\
(0.116)\end{array}$ & $\begin{array}{c}0.015 \\
(0.011)\end{array}$ & - & - \\
\hline $\begin{array}{l}1965 * \text { Other agric. } \\
\text { workers/voter }\end{array}$ & $\begin{array}{l}-0.004 \\
(0.011) \\
\end{array}$ & - & - & $\begin{array}{l}-0.119 \\
(0.124) \\
\end{array}$ & $\begin{array}{l}0.003 \\
(0.11) \\
\end{array}$ & - & - \\
\hline $\begin{array}{l}1961^{*} \text { Inquilinos/population } \\
\text { in } 1935\end{array}$ & - & - & - & - & - & - & $\begin{array}{c}-1.068 * * * \\
(0.379) \\
\end{array}$ \\
\hline $\begin{array}{l}1965 * \text { Inquilinos/population } \\
\text { in } 1935\end{array}$ & - & - & - & - & - & - & $\begin{array}{c}-1.373^{* * *} \\
(0.398) \\
\end{array}$ \\
\hline Time dummies $(1961,1965)$ & Yes & Yes & Yes & Yes & Yes & Yes & Yes \\
\hline Time*Province dummies & Yes & Yes & Yes & Yes & Yes & Yes & Yes \\
\hline Other controls & Yes & Yes & Yes & Yes & Yes & Yes & Yes \\
\hline Communa fixed effect & Yes & Yes & Yes & Yes & Yes & Yes & Yes \\
\hline \# obs. & 738 & 738 & 738 & 738 & 738 & 738 & 633 \\
\hline
\end{tabular}

Notes: Standard errors under brackets, ***indicates significance at the $1 \%$ level, $* *$ at the $5 \%$ level and $*$ at the $10 \%$ level. The within R-square ranged between 0.77 and 0.79 , while the between R-square ranged between 0.01 and 0.08 . The additional controls for equations (23), (26) and (27) are the proportion of land under large farms and the population; for equations (24), (25), (28) and (30), they also include the agricultural labour force. 
Table 6: Impact of agrarian relations on votes for the Christian-Democratic parties

\begin{tabular}{|c|c|c|c|c|c|c|c|c|c|}
\hline & \multicolumn{2}{|c|}{ Model 1} & \multicolumn{2}{|c|}{ Model 2} & \multirow{2}{*}{$\begin{array}{c}\text { Model } 3 \\
\text { (34) }\end{array}$} & \multirow{2}{*}{$\begin{array}{c}\text { Model } 4 \\
\text { (35) }\end{array}$} & \multirow{2}{*}{$\begin{array}{c}\text { Model } 5 \\
\text { (36) }\end{array}$} & \multirow{2}{*}{$\begin{array}{c}\text { Model } 6 \\
\text { (33) }\end{array}$} & \multirow{2}{*}{$\begin{array}{c}\text { Using } \\
\text { inq./pop. in } \\
1935 \\
(34)\end{array}$} \\
\hline & (30) & (31) & (32) & (33) & & & & & \\
\hline Inquilino/voter & $\begin{array}{c}-0.268 * * \\
(0.125) \\
\end{array}$ & $\begin{array}{l}-0.123 \\
(0.101) \\
\end{array}$ & $\begin{array}{c}-0.238 * * \\
(0.104) \\
\end{array}$ & $\begin{array}{c}-0.189 * * \\
(0.083) \\
\end{array}$ & $\begin{array}{c}-0.308 * * \\
(0.123) \\
\end{array}$ & $\begin{array}{l}-0.881 \\
(0.795) \\
\end{array}$ & 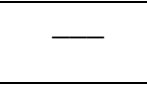 & $\begin{array}{l}-0.073 \\
(0.076) \\
\end{array}$ & - \\
\hline $\begin{array}{l}1965 * \text { Inquilino/vo } \\
\text { ter }\end{array}$ & $\begin{array}{c}0.403^{* * *} \\
(0.059) \\
\end{array}$ & $\begin{array}{c}0.224 * * * \\
(0.060) \\
\end{array}$ & $\begin{array}{c}0.356^{* * *} \\
(0.104) \\
\end{array}$ & $\begin{array}{c}0.089 \\
(0.091) \\
\end{array}$ & $\begin{array}{c}0.025 \\
(0.115) \\
\end{array}$ & $\begin{array}{c}1.927 * * * \\
(0.536) \\
\end{array}$ & $\begin{array}{c}0.190 * * * \\
(0.055) \\
\end{array}$ & $\begin{array}{l}1.225^{*} \\
(0.713) \\
\end{array}$ & - \\
\hline $\begin{array}{l}\text { Other agricultural } \\
\text { workers/voter }\end{array}$ & $\begin{array}{c}0.016 \\
(0.023)\end{array}$ & $\begin{array}{l}-0.010 \\
(0.020)\end{array}$ & - & - & - & $\begin{array}{l}-0.109 \\
(0.161)\end{array}$ & - & - & - \\
\hline $\begin{array}{l}1965 * \text { Other agric. } \\
\text { workers/voter }\end{array}$ & $\begin{array}{c}-0.030 * * * \\
(0.008) \\
\end{array}$ & $\begin{array}{l}-0.011 \\
(0.009)\end{array}$ & - & 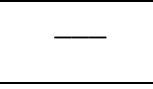 & - & $\begin{array}{l}-0.090 \\
(0.094) \\
\end{array}$ & $\begin{array}{l}-0.142 * \\
(0.008) \\
\end{array}$ & - & - \\
\hline $\begin{array}{l}1965 * \text { Inquilinos/p } \\
\text { opulation in } 1935\end{array}$ & - & - & - & - & - & - & - & - & $\begin{array}{l}0.567 * \\
(0.298)\end{array}$ \\
\hline $\begin{array}{l}\text { Time } \\
\text { dummy:1965 }\end{array}$ & $\begin{array}{c}0.204^{* * * *} \\
(0.015) \\
\end{array}$ & $\begin{array}{c}0.284 * * * \\
(0.031) \\
\end{array}$ & $\begin{array}{c}0.253^{* * *} \\
(0.011) \\
\end{array}$ & $\begin{array}{c}0.264^{* * *} \\
(0.032) \\
\end{array}$ & $\begin{array}{c}0.277 * * * \\
(0.030) \\
\end{array}$ & $\begin{array}{c}0.280 * * * \\
(0.033) \\
\end{array}$ & $0.280 * * *$ & $\begin{array}{c}0.268 * * * \\
(0.030) \\
\end{array}$ & $\begin{array}{c}0.289 * * * \\
(0.033) \\
\end{array}$ \\
\hline 1965*Province & - & Yes & - & Yes & Yes & Yes & $(0.031)$ & Yes & Yes \\
\hline Other controls & & Yes & & Yes & Yes & Yes & Yes & Yes & Yes \\
\hline $\begin{array}{l}\text { Communa fixed } \\
\text { effect }\end{array}$ & Yes & Yes & Yes & Yes & Yes & Yes & Yes & Yes & Yes \\
\hline \# obs. & 492 & 492 & 492 & 492 & 492 & 492 & 492 & 492 & 422 \\
\hline
\end{tabular}

Note: Standard errors under brackets, $* * *$ indicates significance at the $1 \%$ level, $* *$ at the $5 \%$ level and $*$ at the $10 \%$ level. The within R-square ranged between 0.88 and 0.95 , while the between R-square ranged between 0.01 and 0.11 . The additional controls are as in Table 3 . 
Table A1: Description of the main variables used

\begin{tabular}{|c|c|c|c|c|c|}
\hline Variable & \# obs. & Mean & Standard Dev. & Minimum & Maximum \\
\hline Right-wing votes in 1957 & 246 & 0.407 & 0.195 & 0 & 0.914 \\
\hline Right-wing votes in 1961 & 246 & 0.352 & 0.160 & 0 & 0.846 \\
\hline Right-wing votes in 1965 & 246 & 0.174 & 0.111 & 0 & 0.577 \\
\hline $\begin{array}{l}\text { Left and Christian-Democrat votes in } \\
1957\end{array}$ & 246 & 0.161 & 0.141 & 0 & 0.778 \\
\hline $\begin{array}{l}\text { Left and Christian-Democrat votes in } \\
1961\end{array}$ & 246 & 0.330 & 0.134 & 0.041 & 0.792 \\
\hline $\begin{array}{l}\text { Left and Christian-Democrat votes in } \\
1965\end{array}$ & 246 & 0.575 & 0.140 & 0.212 & 0.891 \\
\hline Christian-Democrat votes in 1957 & 246 & 0.069 & 0.144 & 0 & 0.736 \\
\hline Christian-Democrat votes in 1961 & 246 & 0.138 & 0.094 & 0.007 & 0.594 \\
\hline Christian-Democrat votes in 1965 & 246 & 0.371 & 0.111 & 0 & 0.629 \\
\hline $\begin{array}{l}\text { Ratio of inquilinos in } 1957 \text { to the } \\
\text { number of registered voters in } 1957\end{array}$ & 246 & 0.165 & 0.144 & 0 & 0.832 \\
\hline $\begin{array}{l}\text { Ratio of inquilinos in } 1961 \text { to the } \\
\text { number of registered voters in } 1961\end{array}$ & 246 & 0.118 & 0.107 & 0 & 0.599 \\
\hline $\begin{array}{l}\text { Ratio of inquilinos in } 1965 \text { to the } \\
\text { number of registered voters in } 1965\end{array}$ & 246 & 0.083 & 0.084 & 0 & 0.449 \\
\hline $\begin{array}{l}\text { Proportion of inquilinos in } 1957 \text { in the } \\
\text { agricultural labour force in } 1957\end{array}$ & 246 & 0.162 & 0.104 & 0 & 0.552 \\
\hline $\begin{array}{l}\text { Proportion of inquilinos in } 1961 \text { in the } \\
\text { agricultural labour force in } 1961\end{array}$ & 246 & 0.020 & 0.016 & 0 & 0.076 \\
\hline $\begin{array}{l}\text { Proportion of inquilinos in } 1965 \text { in the } \\
\text { agricultural labour force in } 1965\end{array}$ & 246 & 0.088 & 0.059 & 0 & 0.327 \\
\hline $\begin{array}{l}\text { Proportion of inquilinos in } 1957 \text { in the } \\
\text { population in } 1957\end{array}$ & 246 & 0.021 & 0.017 & 0 & 0.068 \\
\hline $\begin{array}{l}\text { Proportion of inquilinos in } 1961 \text { the } \\
\text { population in } 1961\end{array}$ & 246 & 0.020 & 0.016 & 0 & 0.076 \\
\hline $\begin{array}{l}\text { Proportion of inquilinos in } 1965 \text { in the } \\
\text { population in } 1965\end{array}$ & 246 & 0.018 & 0.017 & 0 & 0.086 \\
\hline $\begin{array}{l}\text { Ratio of other agricultural workers in } \\
1957 \text { to the number of registered voters } \\
\text { in } 1957\end{array}$ & 246 & 1.368 & 1.019 & 0.005 & 6.874 \\
\hline $\begin{array}{l}\text { Ratio of other agricultural workers in } \\
1961 \text { the number of registered voters in }\end{array}$ & 246 & 1.204 & 0.862 & 0.004 & 4.267 \\
\hline
\end{tabular}




\begin{tabular}{|c|c|c|c|c|c|}
\hline 1961 & & & & & \\
\hline $\begin{array}{l}\text { Ratio of other agricultural workers in } \\
1965 \text { to the number of registered voters } \\
\text { in } 1965\end{array}$ & 246 & 1.066 & 0.866 & 0.002 & 5.066 \\
\hline $\begin{array}{l}\text { Proportion of inquilinos in } 1935 \text { in the } \\
\text { population in } 1935\end{array}$ & 211 & 0.038 & 0.025 & 0 & 0.136 \\
\hline $\begin{array}{l}\text { Proportion of inquilinos in } 1957 \text { in the } \\
\text { agricultural labour force in } 1957\end{array}$ & 246 & 0.117 & 0.065 & 0 & 0.298 \\
\hline $\begin{array}{l}\text { Proportion of inquilinos in } 1961 \text { in the } \\
\text { agricultural labour force in } 1961\end{array}$ & 246 & 0.095 & 0.053 & 0 & 0.227 \\
\hline $\begin{array}{l}\text { Proportion of inquilinos in } 1965 \text { in the } \\
\text { agricultural labour force in } 1965\end{array}$ & 246 & 0.078 & 0.049 & 0 & 0.246 \\
\hline $\begin{array}{l}\text { Number of other agricultural workers } \\
\text { in } 1957\end{array}$ & 246 & 2219 & 1714 & 0 & 11857 \\
\hline $\begin{array}{l}\text { Number of other agricultural workers } \\
\text { in } 1961\end{array}$ & 246 & 2641 & 1963 & 89 & 14896 \\
\hline $\begin{array}{l}\text { Number of other agricultural workers } \\
\text { in } 1965\end{array}$ & 246 & 3063 & 2275 & 102 & 17934 \\
\hline Population in 1957 & 246 & 22918 & 31720 & 1164 & 246067 \\
\hline Population in 1961 & 246 & 25657 & 37219 & 1076 & 259130 \\
\hline Population in 1965 & 246 & 28182 & 42255 & 965 & 281851 \\
\hline Number of votes in 1957 & 246 & 2876 & 4054 & 65 & 43599 \\
\hline Number of votes in 1961 & 246 & 4299 & 5470 & 131 & 34901 \\
\hline Number of votes in 1965 & 246 & 7248 & 11440 & 76 & 86664 \\
\hline $\begin{array}{l}\text { Share of total area operated by farms } \\
\text { over } 200 \text { hectares in } 1957\end{array}$ & 246 & 0.741 & 0.213 & 0 & 0.997 \\
\hline $\begin{array}{l}\text { Share of total area operated by farms } \\
\text { over } 200 \text { hectares in } 1961\end{array}$ & 246 & 0.724 & 0.213 & 0 & 0.994 \\
\hline $\begin{array}{l}\text { Share of total area operated by farms } \\
\text { over } 200 \text { hectares in } 1965\end{array}$ & 246 & 0.706 & 0.223 & 0 & 0.998 \\
\hline
\end{tabular}

Note: Population, occupation and land concentration figures for 1957 and 1961 were obtained by linear interpolation from the 1955 and the 1965 agricultural censuses. 